\title{
Determinants of postharvest losses along smallholder producers maize and Sweetpotato value chains: an ordered Probit analysis
}

\author{
Apurba Shee $^{1}$ (D) $\cdot$ Sarah Mayanja ${ }^{2} \cdot$ Eria Simba $^{3} \cdot$ Tanya Stathers $^{1} \cdot$ Aurelie Bechoff $^{1} \cdot$ Ben Bennett $^{1}$
}

Received: 22 March 2019 / Accepted: 2 July 2019 / Published online: 20 July 2019

(C) The Author(s) 2019

\begin{abstract}
Postharvest loss reduction throughout commodity value chains is an important pathway to food and nutrition security in subSaharan Africa. However, lack of understanding of the location and share of the losses and associated factors along the postharvest value chains remains a major challenge to operationalizing postharvest loss mitigation strategies. This paper assesses the determinants of postharvest losses at each postharvest stage of maize and sweetpotato (white fleshed and orange fleshed) value chains for smallholder farmers using our cross-sectional field survey data from two districts in Uganda. An ordered probit model estimation reveals that self-reported perceptions of the level of quantitative postharvest losses at different stages of commodity value chains are influenced by socio-economic factors as well as existing postharvest handling and storage practices. Increased years of education and training received on postharvest management are related to lower perceived levels of postharvest losses at key stages of value chains. Lower perceived postharvest losses are also associated with: at transport to homestead the use of sacks and bicycles as opposed to the use of baskets or transporting by trucks; at drying the use of tarpaulins as opposed to use of plastic sheets; shelling using bare-hands as opposed to beating cobs in sack with sticks; storage in a brick and mortar store as opposed to storing in living room in the house.
\end{abstract}

Keywords Maize and sweetpotato value chain $\cdot$ Postharvest losses $\cdot$ Smallholder producers $\cdot$ Ordered probit model

JEL classifications Q180 · Q120

Apurba Shee

a.shee@gre.ac.uk

Sarah Mayanja

S.Mayanja@cgiar.org

Eria Simba

eriasimba@gmail.com

Tanya Stathers

T.E.Stathers@greenwich.ac.uk

Aurelie Bechoff

A.Bechoff@greenwich.ac.uk

Ben Bennett

Ben.Bennett@greenwich.ac.uk

Natural Resources Institute, University of Greenwich, Chatham, UK

2 International Potato Center (CIP), Kampala, Uganda

3 National Agricultural Research Organisation (NARO), Entebbe, Uganda

\section{Introduction}

Postharvest loss of food crops is a global challenge to attainment of the sustainable development goals such as zero hunger and responsible consumption and production. Reduction of postharvest food loss is important for sustainably improving food and nutrition security. In Sub-Saharan Africa (SSA), postharvest loss is particularly important because not only is agricultural productivity low, but about 374 million people experience severe food insecurity (FAO et al. 2018). There is a renewed international attention to reducing postharvest food losses following the African Union member states and United Nations pledging to halve food losses by 2025 and 2030, respectively. Overall, food losses can be measured in quantitative and qualitative terms although most of the research to date has focused on quantitative measure (Sheahan and Barrett 2017). Quantitative losses occur when the actual physical amount of food reduces over time and space, while qualitative losses occur through the loss of nutrients, viability, visual aesthetic appeal or breakage or contamination of food 
amongst other factors (Sheahan and Barrett 2017). Large amounts of foods are physically lost at different stages as food commodities move across their value chains. According to the Food and Agriculture Organization (FAO) of the United Nations, each year about one-third of all food produced for human consumption is lost world-wide. ${ }^{1}$ In SSA, the physical loss of food has been approximately estimated as $37 \%$ or 120 $170 \mathrm{~kg}$ per year per capita (FAO 2011). The World Bank et al. (2011) estimate the value of postharvest loss per year in SSA for all grains to be about $\$ 4$ billion, which is more than the value of food aid received in SSA over last decade. The volume and value of these postharvest loss estimates are alarming highlighting the urgency to better understand and reduce postharvest food losses.

The magnitude of farm-level postharvest quantitative losses reported in the literature vary widely. The African Postharvest Losses Information System (APHLIS) www. aphlis.net uses locally-contextualised science-based estimates of the losses occurring at each postharvest stage, estimating that maize postharvest dry weight losses in Uganda from 2008 to 2016 ranged from 17.2 to $23.8 \%$, equating to an annual national loss of between 320,000 and $465,000 \mathrm{t}$ of maize (APHLIS 2018). By maize postharvest stage, APHLIS estimates harvesting losses of $6.4-16.4 \%$ occurred in Uganda during this period, with a further $4.0 \%$ during further drying, $1.3 \%$ during shelling, $2.4 \%$ during transport to farm, and $1.2-$ $5.9 \%$ during five to eight months of farm-level storage (APHLIS 2018). A recent study of maize postharvest losses in Apac and Lira districts of northern Uganda, reported estimates (based on a combination of measurements and farmers' perceptions) of quantitative losses of $1.9-4.7 \%$ at harvesting due to spillage, $3 \%$ at drying, $4 \%$ during threshing, $10 \%$ during on-farm storage (plus up to $50 \%$ qualitative loss due to the presence of aflatoxin levels $>10 \mathrm{ppb}$ ), $5 \%$ at milling (FAO et al. forthcoming 2019). While a postharvest loss perceptions survey with focus groups of farmers in Uganda in 2013, did not report perceived levels of loss by postharvest activity stage, but identified the perceived major loss-causing factors for maize as spillage, pests (weevils, moulds and rodents), theft, high moisture content (inherent or wetting), poor quality (discolouration, broken grains); and for sweetpotato and cassava as bruises, breakages, theft, vermin and rodents (AGRA 2014). The FAO (2011) Global Food Loss and Food Waste study similarly estimates cereal losses across SSA of about $6 \%$ during harvesting and $8 \%$ during the other postharvest handling and storage stages. In a comprehensive review Affognon et al. (2015) estimate the magnitude of postharvest loss in six SSA countries and report maize loss levels from 5.6 to $25.5 \%$. Using Living Standard Measurement Survey (LSMS) data in Ethiopia, Hengsdijk and de Boer (2017) report average self-reported postharvest cereal loss to be about $24 \%$

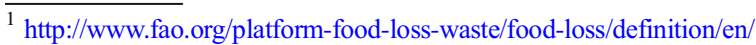

amongst the $10 \%$ of households that reported any postharvest loss. In the LSMS survey, an average maize postharvest loss of between 21 and $27 \%$ of total maize production, was reported by smallholder farmers, but it is notable that few farmers responded stating they had any postharvest loss (i.e. just $7 \%$ in Malawi, 22\% in Uganda, and $<20 \%$ in Tanzania) (Hengsdjik and de Boer, 2017). However, there were a very high number of records ( $>88 \%)$ with 'missing data' on self-reported postharvest cereal losses in the LSMS Malawi and Tanzania (2008/09 to 2012/13) datasets, the reason for such a highincidence of missing data is unknown but would preclude most further analysis of the postharvest loss figures (Hengsdijk and de Boer 2017).

Sweetpotato roots, on the other hand, are more perishable than maize, and are reported to suffer significantly higher postharvest losses than maize in SSA. The meta-analysis by Affognon et al. (2015) reports the magnitude of quantitative losses as high as $45-69 \%$ for sweetpotato. More recently, Parmar et al. (2017) report farm-level harvesting losses of 5 to $20 \%$ for the sweetpotato value chain in Ethiopia.

There have been significant efforts in developing countries to reduce postharvest food loss, however with limited success (Sheahan and Barrett 2017). Storage loss interventions have dominated, including in recent years the development and promotion of hermetic storage technologies (bags and silos). Numerous recent studies (such as Tefera et al. 2011; Bokusheva et al. 2012; Gitonga et al. 2013; Baoua et al. 2014; Ng'ang'a et al. 2016; Ndegwa et al. 2016; Mlambo et al. 2017; Abass et al. 2014) have shown that hermetic technologies can reduce postharvest losses and have a positive impact on households' food and income security. Omotilewa et al. (2018) implemented improved postharvest storage technology in Uganda and showed that improved storage not only increases food security, but also promotes the use of hybrid maize varieties. Although such studies indicate positive impacts of improved postharvest storage in reducing food losses and in improving food security the adoption and use of these technologies is currently still low in SSA (Gitonga et al. 2013; Tesfaye and Tirivayi 2018).

Postharvest losses occur along the entire value chain of a commodity and the value chain stages vary significantly by crop and regional environment. One of the main challenges to postharvest loss reduction is the lack of empirical information on losses and their determinants along the crop value chains (Hodges et al. 2011; Prusky 2011; Affognon et al. 2015). Recent literature reviews such as Affognon et al. (2015) highlight the importance of understanding at which nodes in the value chains losses occur, at what levels and what socioeconomic factors influence such losses. Hodges et al. (2011) assert the main postharvest issue in developing countries as inefficient postharvest agricultural systems. The positioning of loss within the postharvest value chain is important because it can impact the value of the commodity. For example, a 5\% 
quantity loss at marketing stage can be valued differently from a similar scale of loss at the harvest level. This is because prices usually increase as commodities move from one node of the value chain to another further downstream. So, the cost of losses increases at the later stages in the value chain. Hence, preventing losses at the later stage of value chain may have greater overall value compared to reducing losses at the earlier stages. To deliver effective postharvest loss reduction and to make a commodity value chain efficient it is important to investigate the extent of losses and the factors influencing them at each stage.

Physical postharvest losses at different stages of commodity value chains are influenced by socio-economic factors as well as the postharvest methods currently practiced (Harris and Lindblad 1978). Recent reviews such as Affognon et al. (2015) and Sheahan and Barrett (2017) highlight that the imperfect human handling of crops along the value chain is widespread in African agriculture and often results in postharvest losses. Along with sub-optimal postharvest practices, poor road, transport and market infrastructure throughout SSA result in postharvest losses (Sheahan and Barrett 2017). Food is lost throughout the supply chains; from production to processor to retailer to end consumer. In this study, we specifically focus on food crop value chains from the perspective of smallholder farmers rather than on the value chain stages managed by processors, retailers, and consumers. In SSA, the majority of the food lost or wasted at or after harvest occurs during farm-level (i.e., for cereal crops estimated/assumed losses at each of the following stages are: harvesting (6\%); postharvest handling and storage (8\%); processing and packaging (3.5\%); distribution (2\%); and consumption (1\%); and for root and tuber crops the equivalent figures are $14 \%, 18 \%$, $15 \%, 5 \%$ and $2 \%$ respectively) (FAO 2011).

The main research questions this paper intends to address are: what are the determinants of postharvest losses at various stages of the value chains for smallholder producers of maize, and sweet potato (White Fleshed sweetpotato, WFSP), and Orange Fleshed sweetpotato, OFSP)? are the determinants different for different stages of a value chain? what are the extent of influence by the determining factors? To answer these questions, we set up an experimental framework to study each node of the maize, fresh WFSP and OFSP value chains, and traced the commodities from farm production to market. The study was conducted in Omoro and Mpigi districts in Uganda, where 215 farmers growing maize and sweetpotato were randomly selected and interviewed. We assess the determinants of postharvest losses in each stage of the maize, WFSP, and OFSP value chains for smallholder farmers using cross-sectional data. We estimate an ordered probit model (Davidson and MacKinnon 2003; Wooldridge 2010) at each stage to identify the determinants of losses along the value chains for the three crops, an experimental protocol that we have yet to find elsewhere in the literature.
The paper unfolds in the following way. We first present a postharvest value chain system and the activities for maize and sweetpotato. Research design and data description are presented in the following section, where we summarize farmers' socio-economic background information. This includes commodity value chain activities and self-reported postharvest losses farmers experienced at each node of the commodity value chain in the previous season. We then describe the econometric methodology to identify the determinants of postharvest losses along the value chains. Finally, we present and discuss the estimation results, followed by concluding comments.

\section{Smallholders' postharvest value chain for maize and sweetpotato}

A postharvest agricultural system for a smallholder producer is a chain of interconnected activities from the time of harvest to the delivery of foods to market. After harvesting, agricultural food crops go through several procedures such as drying, storing, processing, transporting, selling, consumption and disposal. This system of interconnected activities and procedures is called value chain where the stages may vary significantly by crop (Gibbon and Ponte 2005). Postharvest losses (both quantitative and qualitative) can occur in any postharvest stage of a commodity value chain. The level of loss can be influenced by numerous factors such as crop perishability, mechanical damage during a value chain activity, exposure to temperature, rain, and humidity, pest infestation, inappropriate processing and storage techniques, transport etc. (World Bank et al. 2011; Kaminski and Christiaensen 2014; Affognon et al. 2015; Hengsdijk and de Boer 2017; Sheahan and Barrett 2017). Since the stages of the value chain and the losses associated with each stage vary by commodity, we examine separately the value chain stages and associated activities for maize, WFSP and OFSP. Maize, is typically dried after harvest to render it more durable which enables it to be stored for many months by smallholder farmers and other value chain actors. Fresh sweetpotato roots, on the other hand, have a higher water content and are more perishable, and cannot be stored for long durations at smallholder farmer level in SSA, although if the fresh roots are processed into dried chips or chunks they then can be stored for several months (Stathers et al. 2013).

The main maize postharvest value chain activity stages along with the timing of the activities in our study area are depicted in Fig. 1. After maturity, maize cobs are harvested, then dehusked and transported, usually by headload or bicycle, to the homestead. Drying is done mostly on tarpaulin or on bare soil after which shelling is conducted either by placing the cobs in a sack and beating them with sticks, or by using bare hands to remove the grains, or by using manually- 
Fig. 1 Postharvest stages for smallholders' maize value chain in Uganda

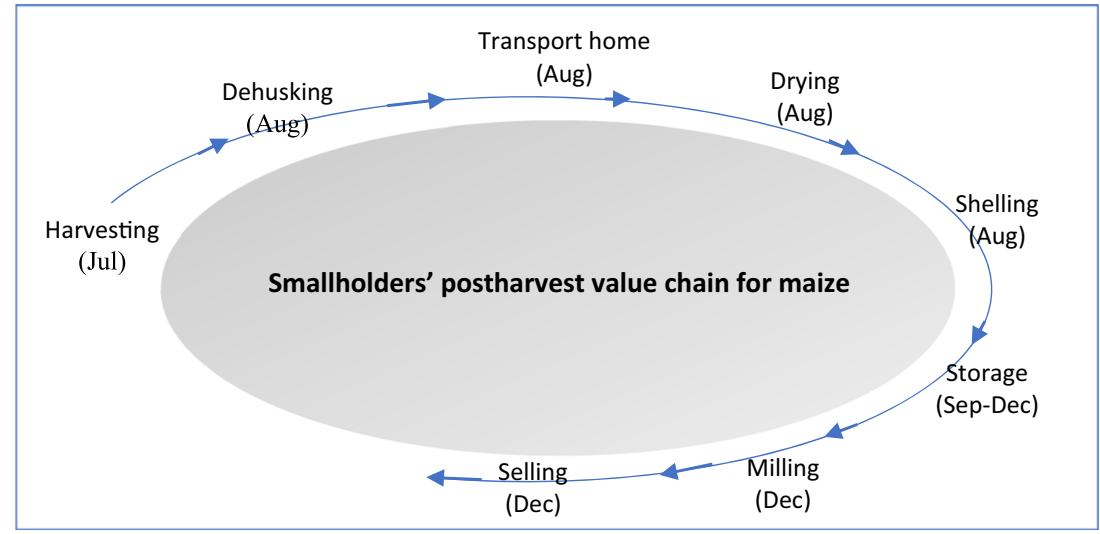

operated shelling machines. Although use of shelling machines or the process of beating cobs in sacks may be timeefficient compared to manually removing all the kernels from the cob, these methods can cause physical damage (breakage and cracking) to grains. Following shelling, most households winnow the grain to remove the chaff and other material. Then, the grains are typically stored in a living room in the house or in a brick and mortar store room. During storage, the moisture content of the grain is a key factor for deterioration, and heat can also damage the grain at this stage. Depending on the environmental conditions during storage and on the grain protection method used, insect pests can cause weight losses of up to 30\% (Mvumi et al. 1995; Stathers et al. 2013). Fungal growth can also cause losses in quality during storage, especially if the grain was not dried sufficiently or is wetted during storage (Stathers et al. 2013). Insufficient pre-storage drying can result in the accumulation of mycotoxins during storage (Hodges et al. 2011). Weather and climate variability may thus influence postharvest losses severely. Given that most farmers rely on sun-drying, unseasonal rains and unfavourable weather conditions can result in rewetting and insufficient drying, resulting in mould growth, discoloration, and insect pest damage (Hodges et al. 2011).

Sweet potato is a nutritious staple food crop grown in all regions of Uganda (Bashaasha et al. 1995). Most Ugandan farmers grow WFSP and increasingly more are also growing OFSP for food and income generation through direct sale of fresh or dried sweetpotato chips (Mwanga and Ssemakula 2011). Fresh sweetpotato roots are bulky and usually contain about 63-83\% moisture (Osundahunsi et al. 2003; Aina et al. 2009) and have a short shelf-life. Typical sweetpotato postharvest value chain activities along with their timings are depicted in Fig. 2. Smallholders generally harvest the crop in a piecemeal fashion for several weeks using sticks or hoes, sometimes finishing by complete harvesting of the whole field if the land is required for the next crop or all the remaining roots are to be sold. Sweetpotato roots are then transported usually by headload or bicycle to the homestead. Freshly
Fig. 2 Postharvest stages for smallholders' sweetpotato value chain in Uganda

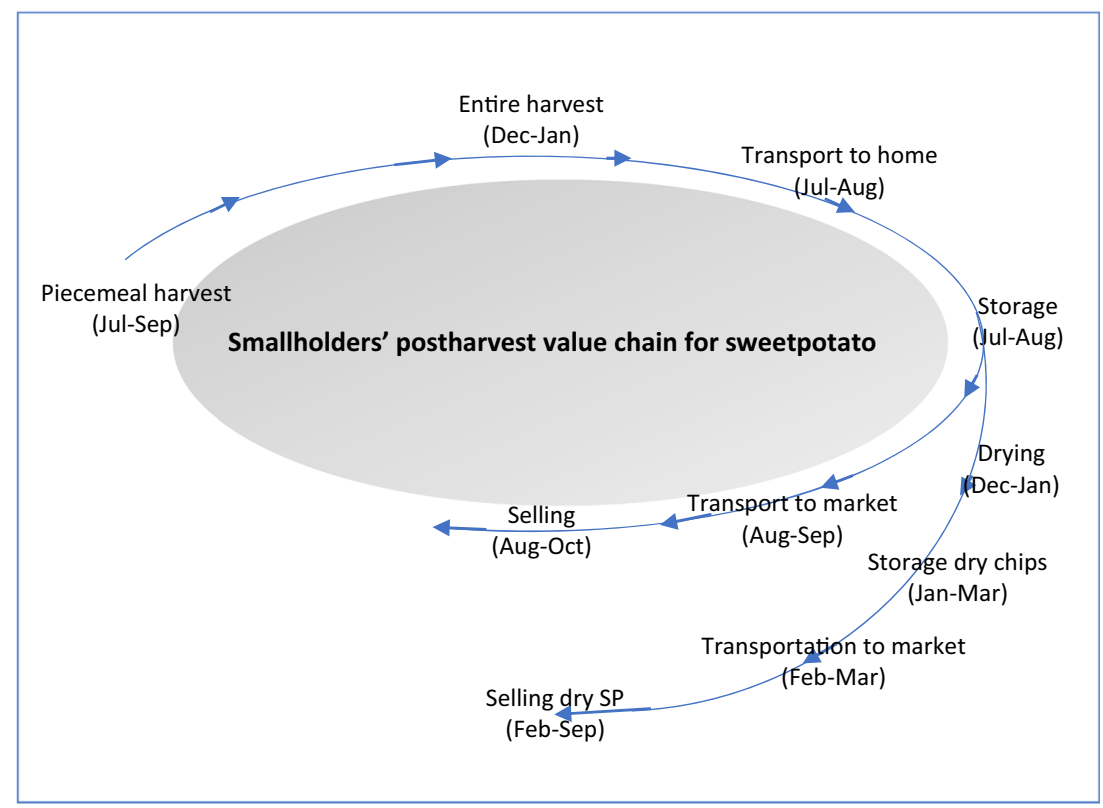


harvested roots are then stored either in the living room or kitchen hut, usually loose and occasionally in woven polypropylene sacks. Roots to be used as food will be cooked that day or the following one, while those to be sold will be transported to the local market, or in some cases sweetpotato roots are sold at the farmgate. About $20 \%$ of our sample WFSP farmers ( 35 out of 181 ) dry about $25 \%$ of their sweetpotato while $40 \%$ of the sample OFSP farmers (33 out of 86 ) dry about $25 \%$ of their sweetpotato roots. Farmers involved in dry value chains chop their sweetpotato roots into small pieces and dry them for about 2-4 days before storing them for food or sending them to market or milling them. Losses can occur at each stage of the fresh and dry sweetpotato value chain due to pests, rotting, and physical damage during harvesting, handling or transport. Weevils (Cylas spp.) are the most prevalent pests reported by Sweetpotato farmers. Apart from physical losses, nutritional losses can occur rapidly in dried and stored OFSP chips, as described for vitamin A by Bechoff et al. (2010).

\section{Data description}

The study is based on a household survey on socioeconomic information and direct elicitation of farmers' self-reported perception of postharvest losses at various stages maize, WFSP, and OFSP value chains. A cross-sectional household survey approach was used to collect data from households that grow maize and sweetpotato (WFSP and OFSP) for food and income in Uganda. The Omoro district in Northern Uganda and the Mpigi district in Central Uganda were purposively selected because smallholder farmers cultivate both maize and sweetpotato in the area. Both the districts are significant producers of maize and sweetpotato in the country. About 29,160 (92\%) and 45,644 (76\%) households are dependent on crop growing for their livelihoods in Omoro and Mpigi, respectively (Uganda Bureau of Statistics 2017). In Omoro, about 43\% and $26 \%$ of the total households are engaged in maize and sweetpotato farming, respectively whereas in Mpigi, about $52 \%$ and $46 \%$ of the total households are engaged in maize and sweetpotato farming, respectively (Uganda Bureau of Statistics 2017). NUTRI-P-LOSS project partners, the International Potato Center (CIP) and the National Agricultural Research Organization (NARO) prepared a sample frame of households in four villages in Omoro district and six villages in Mpigi district, from which equal number of respondents were randomly selected from each of the two districts. Figure 3 shows a map of the study sites and Table 1 presents the distribution of interviewed households.

The data collection was implemented using ComputerAssisted Personal Interviewing (CAPI) by programming the questionnaire in CSPro for tablets. Survey data was collected for 199 maize farmers, 181 white-fleshed sweetpotato farmers and 86 orange-fleshed sweetpotato farmers. The data collected included information on socio-economic status, demographic, postharvest practices, and farmer's self-reported perception of their quantitative postharvest losses experienced in the previous season.

\subsection{Socioeconomic background}

An overview of the socio-economic background of households cultivating maize, WFSP and OFSP is provided in Table 2. The table presents the summary of means and significance tests of equality of means among two districts, Omoro and Mpigi for all the three crops. We describe the socioeconomic background of the households, first for maize and then for WFSP and OFSP. For households cultivating maize, about $53 \%$ of the respondents are females who usually work together with their spouses on their farms. About $76 \%$ of the respondents are either married (monogamous and polygamous) or living together. The average age of the respondents is 41 years, the mean age of respondents in Mpigi (42) being significantly higher than that in Omoro (38 years). The average number of years of education of the respondents is about 6 years. Average total land size is about 3.85 acres whereas average land size used for maize production in the previous year is 1.43 acres, implying that the farmers are mostly small to medium scale producers. The average land size and land size for maize are significantly higher in Omoro than in Mpigi. About $24 \%$ of respondents reported having received trainings on postharvest loss (PHL) management, offered mostly by nongovernment organizations. A typical maize farmer harvested about 11 bags or $550 \mathrm{~kg}$ of maize grain in the previous season translating to an average yield of $384 \mathrm{~kg} / \mathrm{acre}$.

For the households cultivating WFSP, about $56 \%$ of the respondent are females. About $76 \%$ of the respondents are either married (monogamous and polygamous) or living together, with the distribution of married or cohabiting respondents significantly higher in Mpigi (80\%) than in Omoro $(70 \%)$. Average age of the respondents is 41 years with this statistic being significantly higher in Mpigi (43 years) compared to Omoro (38 years). Average number of years of education of the respondents is about 6 years. Average total land size is 3.6 acres whereas land size for sweetpotato (all varieties included) cultivated in the previous season is about 0.87 acres. Compared to Mpigi (3.2 acres), average sweetpotato households in Omoro (4 acres) have significantly higher total land size. About $24 \%$ of the respondents reported that they received trainings on postharvest loss management, offered mostly by non-government organizations. A typical WFSP farmer harvested about 7 bags or $700 \mathrm{~kg}$ of fresh WFSP roots in the previous season, and the average harvest amount is significantly higher in Omoro (974 kg) than in Mpigi $(487 \mathrm{~kg})$. The average yield for WFSP reported is about $800 \mathrm{~kg} / \mathrm{acre}$. 
Fig. 3 Map of the study sites

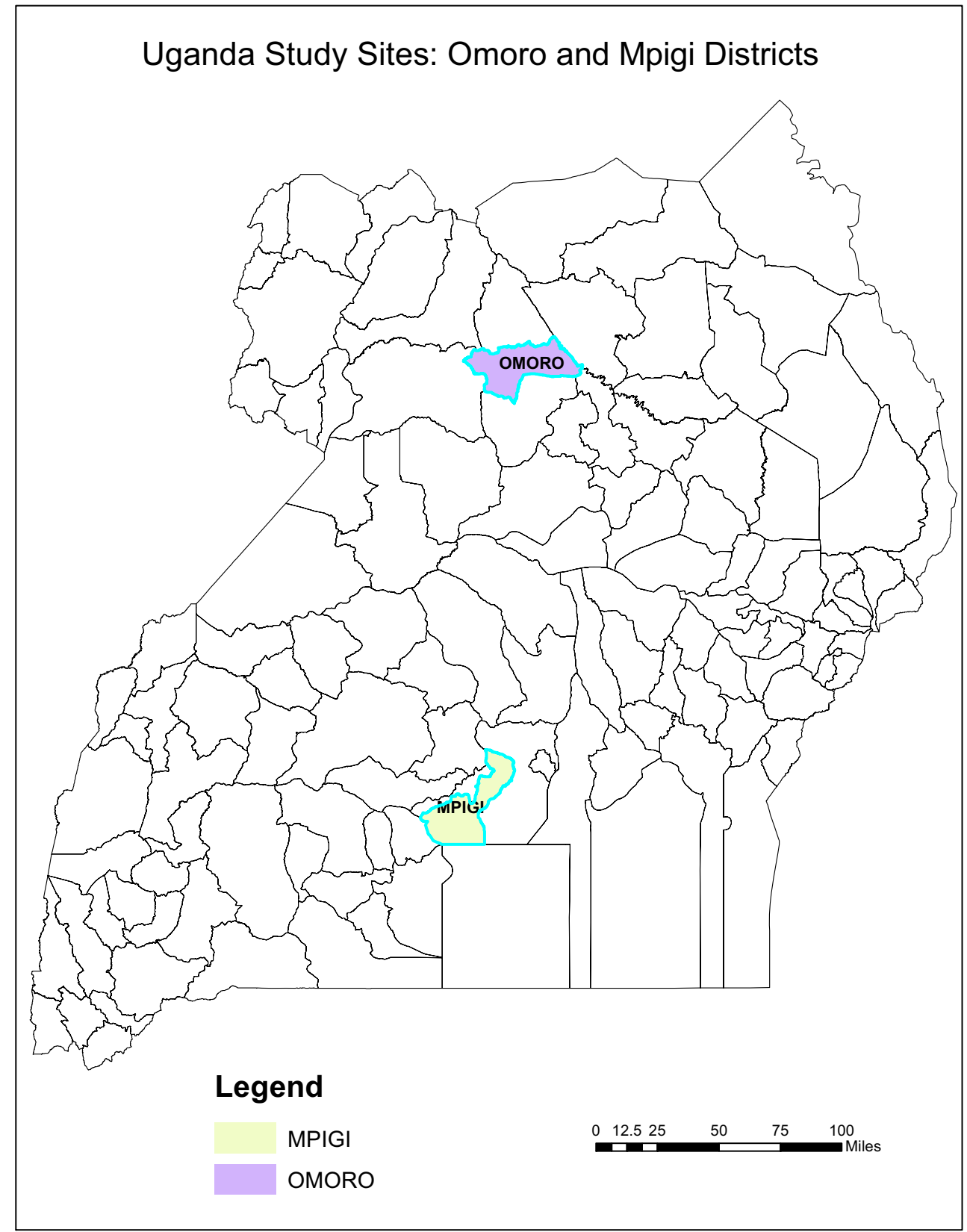

Similarly, OFSP production in the sample is found to be dominated by females with about $58 \%$ of the respondent being females who usually work together with their spouses on their farms. About $74 \%$ of the respondents are either married (monogamous and polygamous) or living together. Average age is about 41 years and average number of years of education of the respondents in the sample is about 6 years. Average total land size is about 4.3 acres whereas average land size for OFSP is 1 acre. Average land size for OFSP is significantly higher in Mpigi (1.25 acres) than in Omoro ( 0.8 acre). About $44 \%$ of the respondents received trainings on postharvest loss management, offered mostly by non-government organizations. A typical OFSP farmer harvested about 11 bags or
$922 \mathrm{~kg}$ of fresh orange fleshed sweetpotato roots in the previous season. The average yield for OFSP reported is about $900 \mathrm{~kg} / \mathrm{acre}$.

\subsection{Estimated quantity losses reported along the value chains}

Special attention was given to eliciting perceived crop losses at each postharvest stage of the three value chains. Estimations of perceived quantitative postharvest losses were elicited through a participatory 'bean exercise' where 100 beans represented their total production, and the farmers who were responsible for postharvest activities were asked to select how 
Table 1 Distribution of interviewed households

\begin{tabular}{|c|c|c|c|c|c|}
\hline District & Villages & No of $\mathrm{HH}$ growing maize & No of HH growing WFSP & No of $\mathrm{HH}$ growing OFSP & Total no of HH \\
\hline Omoro & Acwera & 4 & 2 & 4 & 4 \\
\hline Omoro & Aremo & 39 & 42 & 11 & 45 \\
\hline Omoro & Idopo & 33 & 29 & 18 & 37 \\
\hline Omoro & Lapainat West & 10 & 6 & 11 & 13 \\
\hline Mpigi & Kikoota & 13 & 9 & 12 & 13 \\
\hline Mpigi & Lubanda A & 39 & 37 & 4 & 40 \\
\hline Mpigi & Lubanda B & 16 & 16 & 6 & 16 \\
\hline Mpigi & Lubanda C & 18 & 19 & 8 & 20 \\
\hline Mpigi & Kayunga & 25 & 20 & 10 & 25 \\
\hline Mpigi & Nningye & 2 & 1 & 2 & 2 \\
\hline Total & & 199 & 181 & 86 & 215 \\
\hline
\end{tabular}

many they lost in each stage of a value chain. The elicited losses were therefore not measured but were rather represented by farmers' self-reported perception of the losses experienced in the previous season, either as physical weight of edible mass lost, or the food quantity discarded due to apparent damage or spoilage. The loss estimates were recorded as an ordered range of percentage of quantity losses and were stored as a categorical variable. Farmers loss estimates were then grouped into four ordered ranges; minimal loss (quantitative loss between 0 and 1\%), low loss (between 1 and 3\%), moderate loss (between 3 to 7\%), and high loss (higher than $7 \%$ ). The percentage of respondents reporting losses at each postharvest stage of the maize value chain are presented in Table 3. For the drying and shelling stages more than 50\% of the respondents reported quantitative losses to be higher than $1 \%$. At the drying, shelling, and storage stages, more than
$25 \%$ of respondents reported losses to be in the 'low' range. At the milling stage, about $13 \%$ of respondents reported losses to be 'moderate' and another $13 \%$ respondents reported their losses to in the 'high' range. Ten percent or more of the respondents perceived their losses at harvest, shelling, storage or milling to be 'high'.

Table 4 presents the percentage of respondents reporting four loss categories in WFSP value chain that shows that in entire harvest and storage stages, more than $50 \%$ of the respondents reported losses to be higher than the 'minimal loss' category. Entire harvest is the stage where the highest proportion $(20 \%)$ of the respondents reported their losses to be in the 'high loss' category. Overall, more than $10 \%$ of the respondents reported 'moderate losses' in both harvest (both piecemeal and entire) and storage stages.

Table 2 Socioeconomic background of study households

\begin{tabular}{|c|c|c|c|c|c|c|c|c|c|}
\hline & \multicolumn{3}{|c|}{ HHs cultivating maize } & \multicolumn{3}{|c|}{ HHs cultivating WFSP } & \multicolumn{3}{|c|}{ HHs cultivating OFSP } \\
\hline & Omoro & Mpigi & Total & Omoro & Mpigi & Total & Omoro & Mpigi & Total \\
\hline Female respondent & 0.54 & 0.51 & 0.53 & 0.57 & 0.56 & 0.56 & 0.65 & 0.5 & 0.58 \\
\hline$\%$ of married respondent & 0.71 & 0.79 & 0.76 & $0.70^{*}$ & $0.80^{*}$ & 0.76 & 0.67 & 0.81 & 0.74 \\
\hline Avg age of respondent & $38.27 * *$ & $42.41 * *$ & 40.7 & $38.23 * *$ & $42.75 * *$ & 40.77 & 39.12 & 42.55 & 40.8 \\
\hline Avg years of education of respondent & 5.82 & 6.07 & 5.96 & 5.7 & 5.92 & 5.82 & 6.02 & 6.67 & 6.34 \\
\hline Total land size (Acre) & $4.51 * *$ & $3.37 * *$ & 3.85 & $4.08 *$ & $3.23 *$ & 3.6 & 4.34 & 4.18 & 4.26 \\
\hline Training received on PHL & 0.27 & 0.22 & 0.24 & 0.27 & 0.23 & 0.24 & 0.51 & 0.36 & 0.44 \\
\hline Land size for maize (Acre) & $1.60 *$ & $1.30^{*}$ & 1.43 & & & & & & \\
\hline Land size for sweetpotato (Acre) & & & & 0.84 & 0.89 & 0.87 & & & \\
\hline Land size for sweetpotato (Acre) & & & & & & & $0.80 *$ & $1.25^{*}$ & 1.02 \\
\hline Avg maize harvest (in $50 \mathrm{~kg}$ bag) & 12.05 & 9.77 & 10.7 & & & & & & \\
\hline Avg fresh WFSP harvest (in 100 kg bag) & & & & $9.74 * * *$ & $4.87 * * *$ & 6.92 & & & \\
\hline Avg fresh OFSP harvest (in $100 \mathrm{~kg}$ bag) & & & & & & & 8.31 & 10.16 & 9.22 \\
\hline
\end{tabular}

Key: statistically significant differences between the two districts for each crop type and variable are marked: * significant at $10 \%$; ** significant at $5 \%$; *** significant at $1 \% ; 1$ ha $=2.47$ acres 
Table 3 Percent of respondents indicating Maize loss category

\begin{tabular}{|c|c|c|c|c|c|c|c|c|}
\hline Maize Loss category & Harvesting & Dehusking & Transport to home & Drying & Shelling & Storage & Milling & Selling \\
\hline Minimal loss $(0-1 \%)$ & 58.4 & 57.7 & 67.0 & 43.8 & 49.7 & 50.9 & 54.3 & 65.3 \\
\hline Low loss $(1-3 \%)$ & 22.2 & 23.8 & 19.7 & 30.5 & 26.0 & 26.7 & 19.2 & 22.7 \\
\hline Moderate loss (3-7\%) & 8.1 & 12.2 & 10.6 & 17.7 & 14.1 & 12.4 & 13.3 & 7.3 \\
\hline High loss $(>7 \%)$ & 11.4 & 6.4 & 2.7 & 8.0 & 10.3 & 10.0 & 13.3 & 4.7 \\
\hline Number of observations & 149 & 189 & 188 & 187 & 185 & 161 & 151 & 150 \\
\hline
\end{tabular}

Table 5 presents the percentage of respondents reporting losses in the OFSP value chain. This table shows that in the entire harvest and storage stages, $50 \%$ of the respondents reported their losses to be higher than 'minimal loss' category. Storage is the stage where the highest proportion (24\%) of the respondents reported their losses to be in the 'high loss' category. Apart from storage stage, more than $10 \%$ of the respondents reported 'high losses' in piece-meal and entire harvest stages.

It is important to recognise that this study, as in many others (e.g., FAO 2011; Kaminski and Christiaensen 2014; Hengsdijk and de Boer 2017) is based on respondents' selfreported perceptions of the postharvest losses occurring at each postharvest stage. The loss figures presented are thus 'perceptions' or 'guestimates' and thus highly subjective and not to be confused with 'measured assessments of postharvest loss'. Whilst these 'guestimates' are relatively easy to obtain in comparison to 'objectively measuring losses', their accuracy is not well-understood and may vary by study (Harris and Lindblad 1978; Hodges 2013; Hodges et al. 2014; Stathers et al. 2018; Stathers 2019). One recent postharvest loss assessment study in Ghana (GSARS, 2017) compared 'perceptions of loss' and 'measurements of loss' from 200 farms, and found a weak apparent correlation between them, with measured losses being higher than farmers self-reported perceptions of loss. However, measuring losses is a complex and costly undertaking and requires the use of skilled and experienced data collection teams, repeated visits at different activity stages, significant measurement equipment and well-defined questionnaires customised to the local context and postharvest farming practices. Given the pros and cons of the loss measurement versus perceptions of loss approaches, the Ghana study team conclude that a combination of the two approaches would be practical but notes that further work is necessary to understand how measured and perceived losses can be combined into a sound modelling framework (GSARS, 2017).

\section{Empirical methodology}

Given that our postharvest loss measures are categorical and ordinal, ordered probit or logit models are the most appropriate for analysis (McKelvey and Zavoina 1975; Davidson and MacKinnon 2003; Wooldridge 2010). While the logit assumes a logistic distribution of the error term, the probit assumes a normal distribution. The logistic and normal distributions generally yield similar results in practice. Since the ordered probit model is widely used in empirical econometric application (Davidson and MacKinnon 2003) we briefly describe the ordered probit model. Following Wooldridge (2010), let the ordinal dependent variable y takes the values $\{0,1,2, \ldots, J\}$ for some known integer J. The variable y can be derived (conditional on explanatory variable $\mathrm{x}$ ) from a latent continuous variable $\mathrm{y}^{*}$ (unobservable) which can be determined as follows:

$y_{i}^{*}=x_{i}^{\prime} \beta+u_{i}$

where $u_{i}$ is normally distributed with mean zero and variance one, $\beta$ is a vector of unknown parameter to be estimated, and $x$ is a matrix of independent variables including households' socioeconomic characteristics and existing postharvest handling practices used in each stage of the value chains. Following recent literature (Kaminski and Christiaensen 2014; Hengsdijk and de Boer 2017; Kikulwe et al. 2018) the socio-economic variables we explore include gender (female respondent), age, years of education, land size, harvest amount of the commodity, and postharvest training received. Following Wooldridge, let us assume $\alpha_{1}<\alpha_{2}<\ldots<\alpha_{J}$ to be unknown threshold points and define these thresholds such that

$$
\begin{gathered}
y=0 \text { if } y^{*} \leq \alpha_{1} \\
y=1 \text { if } \alpha_{1}<y^{*} \leq \alpha_{2} \\
\quad: \\
y=J \text { if } y^{*}>\alpha_{J}
\end{gathered}
$$

\begin{tabular}{|c|c|c|c|c|c|c|}
\hline WFSP Loss category & Piece-meal harvest & Entire harvest & Transport to home & Storage & Transport to market & Selling \\
\hline Minimal loss $(0-1 \%)$ & 57.7 & 38.4 & 73.4 & 46.6 & 63.9 & 66.9 \\
\hline Low loss $(1-3 \%)$ & 17.8 & 24.1 & 15.4 & 29.3 & 23.6 & 18.5 \\
\hline Moderate loss (3-7\%) & 11.0 & 17.0 & 7.1 & 20.7 & 8.3 & 9.2 \\
\hline High loss (>7\%) & 13.5 & 20.5 & 4.1 & 3.5 & 4.2 & 5.4 \\
\hline Number of observations & 163 & 112 & 169 & 58 & 72 & 130 \\
\hline
\end{tabular}

Table 4 Percent of respondents indicating WFSP loss category 
Table 5 Percent of respondents indicating OFSP loss category

\begin{tabular}{lllllll}
\hline OFSP Loss category & Piece-meal harvest & Entire harvest & Transport to home & Storage & Transport to market & Selling \\
\hline Minimal loss (0-1\%) & 70.7 & 50 & 76.7 & 45.5 & 68.3 & 63.5 \\
Low loss (1-3\%) & 12 & 24.2 & 12.3 & 24.2 & 14.6 & 20.6 \\
Moderate loss (3-7\%) & 6.7 & 10.3 & 8.2 & 6.1 & 7.3 & 9.8 \\
High loss (>7\%) & 10.7 & 15.5 & 2.7 & 24.2 & 41.1 \\
Number of observations & 75 & 58 & 73 & 33 & 4.8 \\
\hline
\end{tabular}

In our case, y takes on four values 1 ('minimal loss'), 2 ('low loss'), 3 ('moderate loss'), and 4 ('high loss') and the three threshold points are $1 \%, 3 \%$, and $7 \%$. Since the error term is standard normally distributed, each response probability can be written as follows.

$$
\begin{aligned}
& P(y=0 \mid x)=\Phi\left(\alpha_{1}-x^{\prime} \beta\right) \\
& P(y=1 \mid x)=\Phi\left(\alpha_{2}-x^{\prime} \beta\right)-\Phi\left(\alpha_{1}-x^{\prime} \beta\right) \\
& P(y=J \mid x)=1-\Phi\left(\alpha_{J}-x^{\prime} \beta\right)
\end{aligned}
$$

where $\Phi($.$) is the standard normal cumulative distribution.$ This is a generalized version of binary probit model in which parameters $\alpha$ and $\beta$ can be estimated by maximizing the following log-likelihood function:

$$
\begin{aligned}
& L_{i}(\alpha, \beta)=\left[y_{i}=0\right] \log \left[\Phi\left(\alpha_{1}-x^{\prime} \beta\right)\right] \\
& +\left[y_{i}=1\right] \log \left[\Phi\left(\alpha_{2}-x^{\prime} \beta\right)-\Phi\left(\alpha_{1}-x^{\prime} \beta\right)\right]+\ldots+\left[y_{i}=J\right] \log \left[1-\Phi\left(\alpha_{J}-x^{\prime} \beta\right)\right]
\end{aligned}
$$

The marginal effect of an increase in $\mathrm{x}$ on the probability of selecting alternative $\mathrm{j}$ can be written as

$\partial P_{i j} / \partial x_{i}=\left[\phi\left(\alpha_{j-1}-x^{\prime} \beta\right)-\phi\left(\alpha_{j}-x^{\prime} \beta\right)\right] \beta$

where $\phi($.$) is the standard normal density function.$

\section{Results and discussion}

\subsection{Determinants of postharvest physical losses along maize value chain}

We assess maize quantity losses during harvesting, dehusking, transport to homestead, drying, shelling, storage, milling, and selling. Since the outcome dependent variable is ordered and categorical we cannot use ordinary least square and multinomial logit/ probit type models. We use ordered probit model, first developed by McKelvey and Zavoina (1975) and described in empirical methodology section. The results of the determinants of postharvest losses for each node of maize value chain are presented in Table 6 (A and $\mathrm{B}$ ).
Results from panel 1 of Table 6 A show that female respondent and the dummy variable for district (1 for Omoro and 0 for Mpigi) have statistically significant coefficients. During the harvesting stage, female farmers are found to be less likely to perceive their losses to be in the higher loss categories than male farmers. This result is consistent with the finding of Kaminski and Christiaensen (2014) who report perceptions of postharvest losses for maize to be substantially lower for female-headed households compared to male headed households. This may be due to differential perceptions or expectations of harvesting losses between men and women. Although harvesting activity is shared by men and women, usually men are responsible for carrying maize cobs to the homestead, while women are responsible for drying, shelling and storing. Since losses are dependent on environmental conditions, we used a dummy variable for district to control for this condition in the ordered probit estimation. The estimation of this variable indicates that Omoro district is less likely to be in the higher category of losses compared to Mpigi district. The coefficient of hand plucking being negative and significant $(-0.654)$, hand plucking is likely to result in lower losses compared to using machetes to harvest maize.

The coefficient estimates at other nodes of the maize value chain (Table $6 \mathrm{~A} \& \mathrm{~B}$ ), average years of education is significant and negative for transport (to homestead), drying, shelling, and selling, suggesting that at these stages, more educated farmers are less likely to report they experience higher losses. This result is in line with the findings from recent literature such as Mebratie et al. (2015) and Kikulwe et al. (2018) that farmers with more education have lower postharvest loss compared to their counterparts with less education. For the transport, drying and milling stages, the coefficients of the training received on PHL are negative and significant, which indicate that farmers who received training on PHL management are less likely to be related to high losses at transport, drying, and milling stages. About $24 \%$ of our sample of maize farmers had received trainings on PHL management that mainly delivered by NGOs. This result is similar to Abass et al. (2014) who found farmers' lack of training and skills on postharvest management were largely responsible for postharvest food losses. The dummy variable for district is consistently negative for all stages, suggesting that compared to Mpigi district farmers in Omoro district are less likely to 
Table 6 Determinants of PHL along a maize value chain

\begin{tabular}{|c|c|c|c|c|}
\hline Variables & 1Harvesting & 2Dehusking & 3Transport & 4Drying \\
\hline \multicolumn{5}{|l|}{ A } \\
\hline Female respondent & $\begin{array}{l}-0.352 \\
(0.223)\end{array}$ & $\begin{array}{l}-0.291 \\
(0.230)\end{array}$ & $\begin{array}{l}-0.347 * \\
(0.204)\end{array}$ & $\begin{array}{l}0.194 \\
(0.184)\end{array}$ \\
\hline$\%$ of married respondent & $\begin{array}{l}0.251 \\
(0.263)\end{array}$ & $\begin{array}{l}0.318 \\
(0.267)\end{array}$ & $\begin{array}{l}0.0956 \\
(0.232)\end{array}$ & $\begin{array}{l}0.399^{*} \\
(0.217)\end{array}$ \\
\hline Age of respondent & $\begin{array}{l}0.00558 \\
(0.00809)\end{array}$ & $\begin{array}{l}0.000447 \\
(0.00831)\end{array}$ & $\begin{array}{l}-0.00360 \\
(0.00782)\end{array}$ & $\begin{array}{l}-9.07 \mathrm{e}-05 \\
(0.00690)\end{array}$ \\
\hline Avg years of education of respondent & $\begin{array}{l}0.0126 \\
(0.0314)\end{array}$ & $\begin{array}{l}-0.0241 \\
(0.0336)\end{array}$ & $\begin{array}{l}-0.0684 * * \\
(0.0313)\end{array}$ & $\begin{array}{l}-0.0941 \text { *** } \\
(0.0297)\end{array}$ \\
\hline Total land size (Acre) & $\begin{array}{l}-0.0347 \\
(0.0413)\end{array}$ & $\begin{array}{l}-0.0347 \\
(0.0413)\end{array}$ & $\begin{array}{l}0.00355 \\
(0.0401)\end{array}$ & $\begin{array}{l}0.0706^{* *} \\
(0.0349)\end{array}$ \\
\hline Training received on PHL & $\begin{array}{l}0.00621 \\
(0.259)\end{array}$ & $\begin{array}{l}-0.0712 \\
(0.265)\end{array}$ & $\begin{array}{l}-0.406^{*} \\
(0.250)\end{array}$ & $\begin{array}{l}-0.164 \\
(0.213)\end{array}$ \\
\hline Maize harvest (in $50 \mathrm{~kg}$ bag) & $\begin{array}{l}-0.00615 \\
(0.00971)\end{array}$ & $\begin{array}{r}-0.00450 \\
(0.00986)\end{array}$ & $\begin{array}{l}-0.00935 \\
(0.0101)\end{array}$ & $\begin{array}{l}-0.00706 \\
(0.00769)\end{array}$ \\
\hline District & $\begin{array}{l}-0.809 * * * \\
(0.233)\end{array}$ & $\begin{array}{l}-0.447 * * \\
(0.220)\end{array}$ & $\begin{array}{l}0.0116 \\
(0.204)\end{array}$ & $\begin{array}{l}-0.878 * * * \\
(0.195)\end{array}$ \\
\hline Intercept/cut1 & $\begin{array}{l}-0.437 \\
(0.553)\end{array}$ & $\begin{array}{l}-0.0576 \\
(0.549)\end{array}$ & $\begin{array}{l}-0.129 \\
(0.520)\end{array}$ & $\begin{array}{l}-0.496 \\
(0.474)\end{array}$ \\
\hline Intercept/cut2 & $\begin{array}{l}0.301 \\
(0.551)\end{array}$ & $\begin{array}{l}0.687 \\
(0.549)\end{array}$ & $\begin{array}{l}0.614 \\
(0.522)\end{array}$ & $\begin{array}{l}0.468 \\
(0.476)\end{array}$ \\
\hline Intercept/cut3 & $\begin{array}{l}0.715^{*} \\
(0.556)\end{array}$ & $\begin{array}{l}1.053 * \\
(0.553)\end{array}$ & $\begin{array}{l}1.578^{* * * *} \\
(0.548)\end{array}$ & $\begin{array}{l}1.307 * * * \\
(0.484)\end{array}$ \\
\hline \multicolumn{5}{|l|}{ How[Machetes] } \\
\hline Hand Plucking & $\begin{array}{l}-0.654 * * * \\
(0.251)\end{array}$ & & & \\
\hline Other (Specify) & $\begin{array}{l}-0.778 * * * \\
(0.294)\end{array}$ & & & \\
\hline \multicolumn{5}{|l|}{ How[Bare hands] } \\
\hline Sticks & & $\begin{array}{l}0.933 * \\
(0.569)\end{array}$ & & \\
\hline Knives & & $\begin{array}{l}0.0900 \\
(0.235)\end{array}$ & & \\
\hline Other (Specify) & & $\begin{array}{l}0.763^{*} \\
(0.417)\end{array}$ & & \\
\hline \multicolumn{5}{|l|}{ How[Bicycle] } \\
\hline Bare hands/ on head & & & $\begin{array}{l}0.320 \\
(0.228)\end{array}$ & \\
\hline Motrocycle/Tricycle & & & $\begin{array}{l}0.245 \\
(0.278)\end{array}$ & \\
\hline Trucks & & & $\begin{array}{l}0.847^{* * *} \\
(0.425)\end{array}$ & \\
\hline Other (Specify) & & & $\begin{array}{l}0.0943 \\
(0.493)\end{array}$ & \\
\hline \multicolumn{5}{|l|}{ How[Tarpaulin] } \\
\hline On bare soil & & & & $\begin{array}{l}-0.315 \\
(0.234)\end{array}$ \\
\hline Polythene/ Plastic Sheets & & & & $\begin{array}{l}1.091 * * * \\
(0.285)\end{array}$ \\
\hline Other (Specify) & & & & $\begin{array}{l}-0.325 \\
(0.410)\end{array}$ \\
\hline Observations & 149 & 189 & 188 & 187 \\
\hline Variable & 5Shelling & 6Storage & 7Milling & 8Selling \\
\hline \multicolumn{5}{|l|}{ B } \\
\hline Female respondent & $\begin{array}{l}0.157 \\
(0.185)\end{array}$ & $\begin{array}{l}-0.333^{*} \\
-0.205\end{array}$ & $\begin{array}{l}-0.207 \\
(0.218)\end{array}$ & $\begin{array}{l}-0.0990 \\
(0.225)\end{array}$ \\
\hline$\%$ of married respondent & $\begin{array}{l}0.156 \\
(0.216)\end{array}$ & $\begin{array}{l}-0.237 \\
(0.232)\end{array}$ & $\begin{array}{l}0.0659 \\
(0.261)\end{array}$ & $\begin{array}{l}-0.0116 \\
(0.254)\end{array}$ \\
\hline Age of respondent & $\begin{array}{l}0.00533 \\
(0.00697)\end{array}$ & $\begin{array}{l}0.00909 \\
(0.00742)\end{array}$ & $\begin{array}{l}0.0137 \\
(0.00878)\end{array}$ & $\begin{array}{l}-0.000275 \\
(0.00870)\end{array}$ \\
\hline Avg years of education of respondent & $\begin{array}{l}-0.0495^{*} \\
(0.0283)\end{array}$ & $\begin{array}{c}-0.0368 \\
(0.0303)\end{array}$ & $\begin{array}{l}-0.0276 \\
(0.0351)\end{array}$ & $\begin{array}{l}-0.0779 * * \\
(0.0355)\end{array}$ \\
\hline Total land size (Acre) & $\begin{array}{l}0.0222 \\
(0.0337)\end{array}$ & $\begin{array}{l}0.0287 \\
(0.0364)\end{array}$ & $\begin{array}{l}-0.0151 \\
(0.0436)\end{array}$ & $\begin{array}{l}-0.0725 \\
(0.0514)\end{array}$ \\
\hline Training received on PHL & $\begin{array}{l}-0.00217 \\
(0.210)\end{array}$ & $\begin{array}{l}-0.0964 \\
(0.226)\end{array}$ & $\begin{array}{l}-0.772 * * * \\
(0.263)\end{array}$ & $\begin{array}{l}-0.0469 \\
(0.251)\end{array}$ \\
\hline Maize harvest (in $50 \mathrm{~kg}$ bag) & $\begin{array}{l}0.00263 \\
(0.00737)\end{array}$ & $\begin{array}{l}-0.00678 \\
(0.00886)\end{array}$ & $\begin{array}{l}0.000647 \\
(0.00935)\end{array}$ & $\begin{array}{l}0.00925 \\
(0.00988)\end{array}$ \\
\hline District & $\begin{array}{l}-0.491 * * \\
(0.200)\end{array}$ & $\begin{array}{l}-0.578 * * * \\
(0.198)\end{array}$ & $\begin{array}{l}-0.852 * * * \\
(0.222)\end{array}$ & $\begin{array}{l}-0.655^{* * *} \\
(0.314)\end{array}$ \\
\hline Intercept/cutl & $\begin{array}{l}0.315 \\
(0.475)\end{array}$ & $\begin{array}{l}-0.534 \\
(0.485)\end{array}$ & $\begin{array}{l}-0.368 \\
(0.570)\end{array}$ & $\begin{array}{l}-0.347 \\
(0.545)\end{array}$ \\
\hline Intercept/cut2 & $1.058^{* * *}$ & 0.287 & 0.318 & 0.466 \\
\hline
\end{tabular}


Table 6 (continued)

\begin{tabular}{|c|c|c|c|c|}
\hline Variables & 1Harvesting & 2Dehusking & 3Transport & 4Drying \\
\hline & $(0.479)$ & $(0.485)$ & $(0.571)$ & $(0.550)$ \\
\hline Intercept/cut3 & $\begin{array}{l}1.697 * * * \\
(0.487)\end{array}$ & $\begin{array}{l}0.867 * \\
(0.497)\end{array}$ & $\begin{array}{l}0.932 \\
(0.571)\end{array}$ & $\begin{array}{l}0.995^{*} \\
(0.565)\end{array}$ \\
\hline \multicolumn{5}{|l|}{ How[Bare hands] } \\
\hline Hit cobs in sack with sticks & $\begin{array}{l}0.501 * * \\
(0.221)\end{array}$ & & & \\
\hline Sheller & $\begin{array}{l}0.316 \\
(0.251)\end{array}$ & & & \\
\hline Other (Specify) & $\begin{array}{l}0.104 \\
(0.567)\end{array}$ & & & \\
\hline \multicolumn{5}{|l|}{ How[Living room in the house] } \\
\hline Brick \& mortar store room & & $\begin{array}{l}-0.198 \\
(0.292)\end{array}$ & & \\
\hline Other (Specify) & & $\begin{array}{l}-0.626^{* *} \\
(0.271)\end{array}$ & & \\
\hline \multicolumn{5}{|l|}{ How[Commercial hammer mill] } \\
\hline Manual milling & & & $\begin{array}{l}-1.553 * * * \\
(0.526)\end{array}$ & \\
\hline Where[Farmgate] & & & & \\
\hline Local Market & & & & $\begin{array}{l}0.586^{* *} \\
(0.317)\end{array}$ \\
\hline From home & & & & $\begin{array}{l}-0.591^{*} \\
-0.519\end{array}$ \\
\hline Observations & 185 & 161 & 151 & 150 \\
\hline
\end{tabular}

perceive that they incur higher losses. Female farmers are less likely to perceive that they incur high loss for harvest, transport and storage stages than male farmers. Apart from these socio-economic variables, the methods used in each stage of the value chain influence postharvest losses. At de-husking stage, use of sticks, knives etc. is more likely to lead to higher perceived loss compared to using bare hands. Transporting to homestead by truck is more likely to be related to higher loss compared to transporting by bicycle. At drying stage, use of plastic sheets is more likely to lead to higher loss compared to use of tarpaulin. For shelling, beating cobs in sack with sticks is more likely to lead to higher loss compared to shelling with bare hands. At storage stage, storing in brick and mortar store room and use of sacks/containers and are more likely to lead to lower loss compared to storing maize in living room in the house. Similarly, selling in local market is likely to result in higher loss compared to selling at the farmgate. On the other hand, at the milling stage, use of manual milling is perceived to be likely to lead to lower losses compared to the use of commercial hammer mills.

We also estimate marginal effects of ordered probit model described in Eq. (5). Since the marginal effect estimations for all stages of the value chain are consistent with their main parameter estimates, we report the marginal effect estimation only for one stage (milling stage) as an example in Table 7 . The four sets of marginal effects presented in the Table 7 show that farmers who received training on PHL management are $30 \%$ more likely to perceive they experience 'minimal losses', $9 \%$ less likely to perceive they experience 'low losses', $10.7 \%$ less likely to perceive they experience 'moderate losses', and $9.5 \%$ less likely to perceive they experience 'high postharvest losses'. Marginal effects of using a manual milling show that compared to using commercial hammer mills, the use of manual milling will increase the likelihood of the 'minimal loss' category by $45 \%$ and will decrease the likelihoods of the 'low loss', 'moderate loss', and 'high loss' categories by $21 \%, 14 \%, 10 \%$, respectively. Note that these marginal effects sum up to zero for each variable, as the order probit model predicted.

\subsection{Determinants of postharvest physical losses along WFSP value chain}

We assess WFSP quantity losses at piece-meal harvest, entire harvest, transport to homestead, storage, transport to market, and selling. Cross sectional survey data was collected from 181 WFSP farmers from Omoro and Mpigi districts. The results of the determinants of postharvest losses for each node of WFSP value chain are presented in Table 8 (A and B). Results from piece-meal harvest stage show that farmers who received training on PHL and the dummy variable for district have statistically significant negative coefficients. This means, during piece-meal harvest stage, farmers who received training on PHL and farmers from Omoro district are less likely to perceive they experience higher levels of loss. Age of respondent being significantly positive, we conclude that at this stage the older the respondent the higher the likelihood of their being in the higher perceived loss category. Although female respondent variable is not statistically significant, the sign is negative, indicating that female farmers might be less likely to perceive they experience higher categories of losses compared to their male counterpart. Although not statistically significant at $90 \%$ confidence level, the positive sign may mean using knife and spears for piece- 
Table 7 Marginal effects of factors at milling stage of the maize value chain

\begin{tabular}{|c|c|c|c|c|}
\hline Marginal effects: Maize Milling stage & Low loss $(0-1 \%)$ & Moderate loss (1-3\%) & High loss $(3-7 \%)$ & Very high loss $(>7 \%)$ \\
\hline Female respondent & $\begin{array}{l}0.080 \\
(0.085)\end{array}$ & $\begin{array}{l}-0.026 \\
(0.028)\end{array}$ & $\begin{array}{l}-0.029 \\
(0.031)\end{array}$ & $\begin{array}{l}-0.025 \\
(0.027)\end{array}$ \\
\hline$\%$ of married respondent & $\begin{array}{l}-0.026 \\
(0.101)\end{array}$ & $\begin{array}{l}0.008 \\
(0.033)\end{array}$ & $\begin{array}{l}0.009 \\
(0.036)\end{array}$ & $\begin{array}{l}0.008 \\
(0.032)\end{array}$ \\
\hline Age of respondent & $\begin{array}{l}-0.005 \\
(0.003)\end{array}$ & $\begin{array}{l}0.002 \\
(0.001)\end{array}$ & $\begin{array}{l}0.002 \\
(0.001)\end{array}$ & $\begin{array}{l}0.002 \\
(0.001)\end{array}$ \\
\hline Avg years of education of respondent & $\begin{array}{l}0.011 \\
(0.014)\end{array}$ & $\begin{array}{l}-0.004 \\
(0.005)\end{array}$ & $\begin{array}{l}-0.004 \\
(0.005)\end{array}$ & $\begin{array}{l}-0.003 \\
(0.004)\end{array}$ \\
\hline Total land size (Acre) & $\begin{array}{l}0.006 \\
(0.017)\end{array}$ & $\begin{array}{l}-0.002 \\
(0.006)\end{array}$ & $\begin{array}{l}-0.002 \\
(0.006)\end{array}$ & $\begin{array}{l}-0.002 \\
(0.005)\end{array}$ \\
\hline Training received on PHL & $\begin{array}{l}0.300 * * * \\
(0.102)\end{array}$ & $\begin{array}{l}-0.098 * * * \\
(0.042)\end{array}$ & $\begin{array}{l}-0.107 * * * \\
(0.043)\end{array}$ & $\begin{array}{l}-0.095 * * * \\
(0.038)\end{array}$ \\
\hline Maize harvest (in 50 kg bag) & $\begin{array}{l}0.000 \\
(0.004)\end{array}$ & $\begin{array}{l}0.000 \\
(0.001)\end{array}$ & $\begin{array}{l}0.000 \\
(0.001)\end{array}$ & $\begin{array}{l}0.000 \\
(0.001)\end{array}$ \\
\hline District & $\begin{array}{l}0.330 * * * \\
(0.087)\end{array}$ & $\begin{array}{l}-0.108^{* * *} \\
(0.039)\end{array}$ & $\begin{array}{l}-0.118^{* * * *} \\
(0.040)\end{array}$ & $\begin{array}{l}-0.105 * * * \\
(0.035)\end{array}$ \\
\hline Manual milling & $\begin{array}{l}0.449 * * * \\
(0.082)\end{array}$ & $\begin{array}{l}-0.206^{* * *} \\
(0.059)\end{array}$ & $\begin{array}{l}-0.143 * * * \\
(0.035)\end{array}$ & $\begin{array}{l}-0.100^{* * *} \\
(0.028)\end{array}$ \\
\hline Standard errors in parentheses & \multicolumn{4}{|c|}{$* * * p<0.01, * * p<0.05, * p<0.1$} \\
\hline
\end{tabular}

Standard errors in parentheses $* * * \mathrm{p}<0.01$, ** $\mathrm{p}<0.05, * \mathrm{p}<0.1$

Although we provide the estimation of marginal effects only for one stage we estimated marginal effects for all 8 stages of maize value chain. The marginal effect estimations for all stages are consistent with their main parameter estimates. To save space we omit 7 other similar tables of marginal effect estimation, nonetheless, they are available upon request

meal harvesting is more likely to incur higher perceived losses compared to just using the hands.

Results from Table 8 (A and B) show that female respondent is significant and negative for entire harvest, indicating that at this stage female farmers are less likely to perceive high loss compared to their male counterpart. Average years of education is significant and negative for entire harvest and transport to market, suggesting that at these stages, more educated farmers are less likely to be related to higher loss categories. Farmers who received training on PHL management are less likely to incur high losses at piece-meal harvest and storage stage. The dummy variable for district is consistently negative for piece-meal and entire harvest stages. Apart from these socio-economic variables, the methods used in each stage of the value chain influence postharvest losses. At transport to home stage, roots carried in containers (typically woven baskets) and transported by motor cycle are more likely to be related to higher loss compared to roots placed in sacks and carried by hand. On the other hand, storing in a kitchen hut or in brick and mortar store rooms are less likely to be related to higher losses compared to storing in living room in the house. It may be because brick and mortar store rooms are exclusively used for storage, whereas living rooms are usually shared with livestock (e.g., goats and chicken).

We provide marginal effects only for one stage (piece-meal harvest) as an example in Table 9. From the four sets of marginal effects presented in the Table 9, we see that farmers who received training on PHL are $17.7 \%$ more likely to perceive their losses are minimal, $3.7 \%$ less likely to be in low loss category, $5 \%$ less likely to be in moderate loss category, and $9 \%$ less likely to be in high loss category. This is consistent with the results presented in Table 8 (A and B). Marginal effects of age of the respondent show that one-year increase in age is associated with being $0.7 \%$ less likely to be in the minimal loss category, $0.1 \%$ more likely to be in low loss category, $0.2 \%$ more likely to be in moderate loss category, and $0.3 \%$ more likely to be in high loss category. As the order probit model predicted, these marginal effects sum up to zero for each variable.

\subsection{Determinants of postharvest losses along OFSP value chain}

We assess perceived OFSP quantitative postharvest losses at piece-meal harvest, entire harvest, transport to homestead, storage, transport to market, and selling. Cross sectional survey data was collected from 86 OFSP farmers from Omoro and Mpigi districts. The results of the determinants of postharvest losses for each node of OFSP value chain are presented in Tables 10 and 11.

Results from panel 1 show that the coefficient of the number of years of education is statistically significant and negative, suggesting that at piece-meal harvest stage, more educated farmers are less likely to be related to perceiving they have higher losses. Similarly, the coefficient estimate of the number of years of education variable at all other nodes of OFSP value chain is negative, however apart from piece-meal stage, the coefficient is significant only for transport to homestead, transport to market, and selling stages. Hence, improving education and awareness will be an important policy intervention for loss reduction at all the stages of OFSP value chain. Among the 
Table 8 Determinants of PHL along a White Fleshed Sweetpotato value chain

\begin{tabular}{|c|c|c|c|}
\hline Variable & 1Piecemeal & 2Entireharvest & 3Transport home \\
\hline \multicolumn{4}{|l|}{ A } \\
\hline Female respondent & $\begin{array}{l}-0.155 \\
(0.214)\end{array}$ & $\begin{array}{l}-0.431 * * \\
(0.237)\end{array}$ & $\begin{array}{l}-0.175 \\
(0.235)\end{array}$ \\
\hline$\%$ of married respondent & $\begin{array}{l}0.183 \\
(0.251)\end{array}$ & $\begin{array}{l}0.0991 \\
(0.281)\end{array}$ & $\begin{array}{l}-0.0929 \\
(0.272)\end{array}$ \\
\hline Age of respondent & $\begin{array}{l}0.0171 * * \\
(0.00792)\end{array}$ & $\begin{array}{l}-0.00327 \\
(0.00887)\end{array}$ & $\begin{array}{l}0.00100 \\
(0.00882)\end{array}$ \\
\hline Avg years of education of respondent & $\begin{array}{l}0.0140 \\
(0.0294)\end{array}$ & $\begin{array}{l}-0.0899 * * \\
(0.0372)\end{array}$ & $\begin{array}{l}0.00326 \\
(0.0322)\end{array}$ \\
\hline Total land size (Acre) & $\begin{array}{l}0.0133 \\
(0.0419)\end{array}$ & $\begin{array}{l}-0.00487 \\
(0.0340)\end{array}$ & $\begin{array}{l}-0.0120 \\
(0.0392)\end{array}$ \\
\hline Training received on PHL & $\begin{array}{l}-0.451^{* *} \\
(0.233)\end{array}$ & $\begin{array}{l}0.237 \\
(0.245)\end{array}$ & $\begin{array}{l}-0.367 \\
(0.262)\end{array}$ \\
\hline Fresh WFSP harvest (in 100 kg bag) & $\begin{array}{l}0.00614 \\
(0.0127)\end{array}$ & $\begin{array}{l}0.0137 \\
(0.0144)\end{array}$ & $\begin{array}{l}0.000772 \\
(0.0125)\end{array}$ \\
\hline District & $\begin{array}{l}-0.519 * * * \\
(0.219)\end{array}$ & $\begin{array}{l}-0.400^{*} \\
-0.245\end{array}$ & $\begin{array}{l}-0.0537 \\
(0.248)\end{array}$ \\
\hline Intercept/cut1 & $\begin{array}{l}0.730 \\
(0.560)\end{array}$ & $\begin{array}{l}-1.068^{*} \\
(0.619)\end{array}$ & $\begin{array}{l}0.735 \\
(0.600)\end{array}$ \\
\hline Intercept/cut2 & $\begin{array}{l}1.258^{* *} \\
(0.564)\end{array}$ & $\begin{array}{l}-0.406 \\
(0.616)\end{array}$ & $\begin{array}{l}1.367 * * \\
(0.606)\end{array}$ \\
\hline intercept/cut3 & $\begin{array}{l}1.730 * * * \\
(0.567)\end{array}$ & $\begin{array}{l}0.143 \\
(0.617)\end{array}$ & $\begin{array}{l}1.911 * * * \\
(0.618)\end{array}$ \\
\hline How[Hands] & & & \\
\hline Stick & $\begin{array}{l}-0.0280 \\
(0.214)\end{array}$ & & \\
\hline Knife, Spear etc. & $\begin{array}{l}0.141 \\
(0.358)\end{array}$ & & \\
\hline How[Hoes] & & & \\
\hline Hoes and hands & & $\begin{array}{l}0.394 \\
(0.306)\end{array}$ & \\
\hline How[Roots placed sacks and carried b & & & \\
\hline Containers & & & $\begin{array}{l}0.935 * * * \\
(0.332)\end{array}$ \\
\hline Oh head (headload) & & & $\begin{array}{l}0.368 \\
(0.271)\end{array}$ \\
\hline Bicycle & & & $\begin{array}{l}0.258 \\
(0.442)\end{array}$ \\
\hline Other (Specify) & & & $\begin{array}{l}0.814 * \\
(0.419)\end{array}$ \\
\hline Observations & 163 & 112 & 169 \\
\hline B & & & \\
\hline Variable & 4Storage & 5Transport to market & 6Selling \\
\hline Female respondent & $\begin{array}{l}0.381 \\
(0.389)\end{array}$ & $\begin{array}{l}-0.399 \\
(0.386)\end{array}$ & $\begin{array}{l}-0.197 \\
(0.246)\end{array}$ \\
\hline$\%$ of married respondent & $\begin{array}{l}0.117 \\
(0.391)\end{array}$ & $\begin{array}{l}0.176 \\
(0.418)\end{array}$ & $\begin{array}{l}0.131 \\
(0.285)\end{array}$ \\
\hline Age of respondent & $\begin{array}{l}-0.00237 \\
(0.0136)\end{array}$ & $\begin{array}{l}-0.000432 \\
(0.0145)\end{array}$ & $\begin{array}{l}-0.0148 \\
(0.00956)\end{array}$ \\
\hline Avg years of education of respondent & $\begin{array}{l}0.0208 \\
(0.0609)\end{array}$ & $\begin{array}{l}-0.164 * * * \\
(0.0610)\end{array}$ & $\begin{array}{l}-0.0367 \\
(0.0346)\end{array}$ \\
\hline Total land size (Acre) & $\begin{array}{l}0.0688 \\
(0.101)\end{array}$ & $\begin{array}{l}0.0243 \\
(0.0483)\end{array}$ & $\begin{array}{l}-0.0591 \\
(0.0422)\end{array}$ \\
\hline Training received on PHL & $\begin{array}{l}-0.142 * \\
(0.075)\end{array}$ & $\begin{array}{l}0.637 \\
(0.394)\end{array}$ & $\begin{array}{l}0.230 \\
(0.261)\end{array}$ \\
\hline Fresh WFSP harvest (in 100 kg bag) & $\begin{array}{l}0.00296 \\
(0.0184)\end{array}$ & $\begin{array}{l}0.0159 \\
(0.0143)\end{array}$ & $\begin{array}{l}0.00526 \\
(0.0121)\end{array}$ \\
\hline District & $\begin{array}{l}-0.165 \\
(0.383)\end{array}$ & $\begin{array}{l}0.297 \\
(0.440)\end{array}$ & $\begin{array}{l}-0.257 \\
(0.314)\end{array}$ \\
\hline Intercept/cut1 & $\begin{array}{l}-0.174 \\
(0.983)\end{array}$ & $\begin{array}{l}-0.0213 \\
(1.066)\end{array}$ & $\begin{array}{l}-0.502 \\
(0.584)\end{array}$ \\
\hline Intercept/cut2 & $\begin{array}{l}0.676 \\
(0.987)\end{array}$ & $\begin{array}{l}0.902 \\
(1.062)\end{array}$ & $\begin{array}{l}0.156 \\
(0.583)\end{array}$ \\
\hline intercept/cut3 & $\begin{array}{l}1.867 * \\
(1.035)\end{array}$ & $\begin{array}{l}1.576 \\
(1.066)\end{array}$ & $\begin{array}{l}0.735 \\
(0.589)\end{array}$ \\
\hline
\end{tabular}

How[Living room in the house] 
Table 8 (continued)

\begin{tabular}{|c|c|c|c|}
\hline $\begin{array}{l}\text { Kitchen hut } \\
\text { Other (Specify) }\end{array}$ & $\begin{array}{l}-0.943 * * \\
(0.447) \\
-0.961 * * \\
-0.517\end{array}$ & & \\
\hline \multicolumn{4}{|c|}{ How[Sacks in vehicle] } \\
\hline Head loads & & $\begin{array}{l}0.445 \\
(0.974)\end{array}$ & \\
\hline Bicycle & & $\begin{array}{l}0.0793 \\
(0.888)\end{array}$ & \\
\hline Motorbike & & $\begin{array}{l}-0.159 \\
(0.873)\end{array}$ & \\
\hline \multicolumn{4}{|l|}{ Where[Farmgate] } \\
\hline Local Market & & & $\begin{array}{l}0.229 \\
(0.312)\end{array}$ \\
\hline Urban Market & & & $\begin{array}{l}0.379 \\
(0.664)\end{array}$ \\
\hline Observations & 58 & 72 & 130 \\
\hline
\end{tabular}

Standard errors in parentheses $* * * \mathrm{p}<0.01, * * \mathrm{p}<0.05, * \mathrm{p}<0.1$

methods practiced in value chain stages, at the transportation to homestead stage the significance of the variables suggests that transporting OFSP roots to the homestead using motorcycle is more likely to be related to perceived higher losses compared to roots placed in sacks and carried by hand.
We provide marginal effects only for one stage (selling) as an example in Table 12. From the four sets of marginal effects presented in the Table 12, we see that a one-year increase in education is associated with being $4.6 \%$ more likely to be in the 'minimal loss' category, $2 \%$ less likely to be in 'low loss'

Table 9 Marginal effects of factors at piece-meal harvest stage of WFSP value chain

\begin{tabular}{|c|c|c|c|c|}
\hline Marginal effects: WFSP Piecemeal harvest stage & Low loss $(0-1 \%)$ & Moderate loss $(1-3 \%)$ & High loss $(3-7 \%)$ & Very high loss $(>7 \%)$ \\
\hline \multirow[t]{2}{*}{ Female respondent } & 0.061 & -0.013 & -0.017 & -0.031 \\
\hline & $(0.084)$ & $(0.018)$ & $(0.024)$ & $(0.043)$ \\
\hline \multirow[t]{2}{*}{$\%$ of married respondent } & -0.072 & 0.015 & 0.020 & 0.036 \\
\hline & $(0.098)$ & $(0.021)$ & $(0.028)$ & $(0.050)$ \\
\hline \multirow[t]{2}{*}{ Age of respondent } & $-0.007 * *$ & $0.001 * *$ & $0.002 * *$ & $0.003 * *$ \\
\hline & $(0.003)$ & $(0.001)$ & $(0.001)$ & $(0.002)$ \\
\hline \multirow[t]{2}{*}{ Avg years of education of respondent } & -0.006 & 0.001 & 0.002 & 0.003 \\
\hline & $(0.012)$ & $(0.002)$ & $(0.003)$ & $(0.006)$ \\
\hline \multirow[t]{2}{*}{ Total land size (Acre) } & -0.005 & 0.001 & 0.001 & 0.003 \\
\hline & $(0.016)$ & $(0.003)$ & $(0.005)$ & $(0.008)$ \\
\hline \multirow[t]{2}{*}{ Training received on PHL } & $0.177 * *$ & $-0.037 * *$ & $-0.050 *$ & $-0.090 * *$ \\
\hline & $(0.092)$ & $(0.022)$ & $(0.029)$ & $(0.048)$ \\
\hline \multirow[t]{2}{*}{ Fresh WFSP harvest (in $100 \mathrm{~kg}$ bag) } & -0.002 & 0.001 & 0.001 & 0.001 \\
\hline & $(0.005)$ & $(0.001)$ & $(0.001)$ & $(0.003)$ \\
\hline \multirow[t]{2}{*}{ District } & $0.204 * * *$ & $-0.043 * *$ & $-0.058 * *$ & $-0.103 * * *$ \\
\hline & $(0.086)$ & $(0.021)$ & $(0.029)$ & $(0.045)$ \\
\hline \multirow[t]{2}{*}{ Stick } & 0.011 & -0.002 & -0.003 & -0.005 \\
\hline & $(0.084)$ & $(0.018)$ & $(0.024)$ & $(0.042)$ \\
\hline \multirow[t]{2}{*}{ Knife, Spear etc. } & -0.056 & 0.010 & 0.015 & 0.031 \\
\hline & $(0.142)$ & $(0.023)$ & $(0.039)$ & $(0.081)$ \\
\hline
\end{tabular}

Standard errors in parentheses $* * * \mathrm{p}<0.01, * * \mathrm{p}<0.05, * \mathrm{p}<0.1$

Although we provide the estimation of marginal effects only for one stage we estimated marginal effects for all 6 stages of WFSP value chain. The marginal effect estimations for all stages are consistent with their main parameter estimates. To save space we omit 5 other similar tables of marginal effect estimation, nonetheless, they are available upon request 
Table 10 Determinants of PHL along Orange Fleshed Sweetpotato

\begin{tabular}{|c|c|c|c|}
\hline Variable & 1Piecemeal & 2Entireharvest & 3Transport home \\
\hline Female respondent & $\begin{array}{c}0.148 \\
(0.351)\end{array}$ & $\begin{array}{l}0.0374 \\
(0.366)\end{array}$ & $\begin{array}{l}0.315 \\
(0.450)\end{array}$ \\
\hline$\%$ of married respondent & $\begin{array}{l}0.910^{*} \\
(0.467)\end{array}$ & $\begin{array}{c}0.464 \\
(0.415)\end{array}$ & $\begin{array}{l}1.528^{* * *} \\
(0.705)\end{array}$ \\
\hline Age of respondent & $\begin{array}{c}0.0171 \\
(0.0139)\end{array}$ & $\begin{array}{c}-0.00725 \\
(0.0124)\end{array}$ & $\begin{array}{c}0.0206 \\
(0.0139)\end{array}$ \\
\hline Avg years of education of respondent & $\begin{array}{c}-0.121 * * \\
(0.0578)\end{array}$ & $\begin{array}{l}-0.0278 \\
(0.0599)\end{array}$ & $\begin{array}{l}-0.108^{*} \\
(0.0651)\end{array}$ \\
\hline Total land size (Acre) & $\begin{array}{c}0.0531 \\
(0.0584)\end{array}$ & $\begin{array}{c}-0.000531 \\
(0.0401)\end{array}$ & $\begin{array}{l}0.00803 \\
(0.0506)\end{array}$ \\
\hline Training received on PHL & $\begin{array}{l}-0.288 \\
(0.325)\end{array}$ & $\begin{array}{c}0.391 \\
(0.318)\end{array}$ & $\begin{array}{l}0.262 \\
(0.402)\end{array}$ \\
\hline Fresh OFSP harvest (in $100 \mathrm{~kg}$ bag) & $\begin{array}{l}0.00416 \\
(0.0119)\end{array}$ & $\begin{array}{l}0.00540 \\
(0.0110)\end{array}$ & $\begin{array}{l}0.00388 \\
(0.0154)\end{array}$ \\
\hline District & $\begin{array}{c}0.339 \\
(0.329)\end{array}$ & $\begin{array}{l}-0.215 \\
(0.370)\end{array}$ & $\begin{array}{l}-0.501 \\
(0.424)\end{array}$ \\
\hline Intercept/cut1 & $\begin{array}{c}2.308^{* * *} \\
(1.003)\end{array}$ & $\begin{array}{l}-0.139 \\
(1.051)\end{array}$ & $\begin{array}{c}2.745^{* *} \\
(1.384)\end{array}$ \\
\hline Intercept/cut2 & $\begin{array}{c}2.768 * * * \\
(1.014)\end{array}$ & $\begin{array}{c}0.550 \\
(1.049)\end{array}$ & $\begin{array}{c}3.488 * * \\
(1.402)\end{array}$ \\
\hline Intercept/cut3 & $\begin{array}{c}3.135 * * * \\
(1.029)\end{array}$ & $\begin{array}{c}0.928 \\
(1.055)\end{array}$ & $\begin{array}{c}4.361 * * * \\
(1.457)\end{array}$ \\
\hline \multicolumn{4}{|l|}{ How[Hands] } \\
\hline Stick & $\begin{array}{l}0.0354 \\
(0.353)\end{array}$ & & \\
\hline Spear & $\begin{array}{c}0.862 \\
(0.636)\end{array}$ & & \\
\hline \multicolumn{4}{|l|}{ How[Hoes] } \\
\hline Hoes and hands & & $\begin{array}{c}0.396 \\
(0.445)\end{array}$ & \\
\hline \multicolumn{4}{|c|}{ How[Roots placed sacks and carried by hand] } \\
\hline Containers & & & $\begin{array}{c}0.441 \\
(0.799)\end{array}$ \\
\hline Oh head (headload) & & & $\begin{array}{l}0.961^{*} \\
(0.536)\end{array}$ \\
\hline Motorcycle & & & $\begin{array}{c}1.733 * * * \\
(0.553)\end{array}$ \\
\hline Observations & 75 & 58 & 73 \\
\hline
\end{tabular}

Standard errors in parentheses $* * * p<0.01, * * p<0.05, * p<0.1$

category, $1.7 \%$ less likely to be in 'moderate loss' category, and $0.8 \%$ less likely to be in 'high loss' category. This is consistent with the results presented in Tables 10 and 11. As the order probit model predicted, these marginal effects sum up to zero for each variable.

\section{Concluding comments}

Postharvest loss reduction throughout commodity value chains is an important pathway to food and nutrition security in SSA. Large quantities of food crops are physically lost at different stages as food commodities move along their often complex and dynamic value chains. Lack of understanding of the location of losses and associated factors within the postharvest value chains remains a major challenge to operationalizing postharvest loss mitigation strategies. We assess the extent and determinants of perceived postharvest losses in each stage of maize, WFSP and OFSP value chains for smallholder farmers using cross-sectional data from two districts in Uganda. We estimate an ordered probit model at each stage to identify the determinants of selfreported perceived postharvest losses along the value chains for the three crops. Identification of the factors influencing perceived postharvest losses at each node of value chains through rigorous estimation is an important contribution of the paper.

The results show that postharvest physical losses at different stages of the commodity value chains are influenced by socio-economic factors as well as the postharvest methods currently practiced. Among socio-economic variables, more years of education and having received training on PHL management are related to lower (perceived) PHL at key stages of value chains. Gender also plays an important role at some key stages in the value chains, female farmers are found to be less 
Table 11 Determinants of PHL along Orange Fleshed Sweetpotato value chain

\begin{tabular}{|c|c|c|c|}
\hline Variable & 4Storage & 5Transport to market & 6Selling \\
\hline \multirow[t]{2}{*}{ Female respondent } & -0.415 & -0.156 & -0.150 \\
\hline & $(0.499)$ & $(0.531)$ & $(0.370)$ \\
\hline \multirow[t]{2}{*}{$\%$ of married respondent } & 0.249 & $1.942 * *$ & 0.170 \\
\hline & $(0.715)$ & $(0.835)$ & $(0.429)$ \\
\hline \multirow[t]{2}{*}{ Age of respondent } & -0.000947 & -0.0150 & -0.0111 \\
\hline & $(0.0183)$ & $(0.0201)$ & $(0.0146)$ \\
\hline \multirow[t]{2}{*}{ Avg years of education of respondent } & -0.113 & $-0.260 * * *$ & $-0.124 * *$ \\
\hline & $(0.104)$ & $(0.110)$ & -0.0607 \\
\hline \multirow[t]{2}{*}{ Total land size (Acre) } & 0.0793 & -0.0746 & -0.0209 \\
\hline & $(0.0636)$ & $(0.0858)$ & $(0.0445)$ \\
\hline \multirow[t]{2}{*}{ Training received on PHL } & 0.601 & 0.672 & 0.650 \\
\hline & $(0.531)$ & $(0.580)$ & $(0.456)$ \\
\hline \multirow[t]{2}{*}{ Fresh OFSP harvest (in $100 \mathrm{~kg}$ bag) } & 0.00967 & -0.0309 & 0.0152 \\
\hline & $(0.0244)$ & $(0.0260)$ & $(0.0119)$ \\
\hline \multirow[t]{2}{*}{ District } & 0.102 & 0.573 & $-0.753 *$ \\
\hline & $(0.456)$ & $(0.777)$ & -0.426 \\
\hline \multirow[t]{2}{*}{ Intercept/cut1 } & 0.123 & 0.932 & -1.700 \\
\hline & $(1.413)$ & $(1.990)$ & $(1.480)$ \\
\hline \multirow[t]{2}{*}{ Intercept/cut2 } & 0.859 & 1.620 & -0.935 \\
\hline & $(1.419)$ & $(1.984)$ & $(1.465)$ \\
\hline \multirow[t]{2}{*}{ Intercept/cut3 } & 1.064 & 2.084 & -0.212 \\
\hline & $(1.419)$ & $(2.011)$ & $(1.480)$ \\
\hline \multicolumn{4}{|l|}{ How[Living room in the house] } \\
\hline \multirow[t]{2}{*}{ Kitchen hut } & -0.179 & & \\
\hline & $(0.519)$ & & \\
\hline \multirow[t]{3}{*}{ Other (Specify) } & 0.634 & & \\
\hline & $(0.678)$ & & \\
\hline & How $[\mathrm{H}$ & & \\
\hline \multirow[t]{2}{*}{ Bicycle } & & -0.422 & \\
\hline & & $(1.201)$ & \\
\hline \multirow[t]{2}{*}{ Motorbike } & & 1.050 & \\
\hline & & $(1.067)$ & \\
\hline \multicolumn{4}{|l|}{ Where[Farmgate] } \\
\hline \multirow[t]{2}{*}{ Local Market } & & & -0.508 \\
\hline & & & $(0.680)$ \\
\hline \multirow[t]{2}{*}{ Urban Market } & & & 0.599 \\
\hline & & & $(0.636)$ \\
\hline Observations & 33 & 41 & 63 \\
\hline
\end{tabular}

Standard errors in parentheses $* * * \mathrm{p}<0.01, * * \mathrm{p}<0.05, * \mathrm{p}<0.1$

likely to perceive they incur losses compared to their male counterparts. For the postharvest maize value chain, the average number of years of education is associated with a lower likelihood of (perceived) high losses at harvest, transport to homestead, drying, shelling, and selling. Farmers who received training on PHL are less likely to be related to high losses at transport, drying, and milling stages. For WFSP value chain, female respondent, years of education, and farmers who received training on PHL are less likely to be related to high losses at key stages of postharvest value chain. For postharvest OFSP value chain, more educated farmers are found to be less likely to be related to perceived higher loss categories at piece-meal harvest, transport to home stead, transport to market, and selling stages.

We also identified the postharvest handling practices which are more likely to be related to (perceived) high losses at each 
Table 12 Marginal effects of factors at the selling stage of OFSP value chain

\begin{tabular}{|c|c|c|c|c|}
\hline Marginal effects: OFSP Selling stage & Low loss $(0-1 \%)$ & Moderate loss $(1-3 \%)$ & High loss $(3-7 \%)$ & Very high loss $(>7 \%)$ \\
\hline Female respondent & $\begin{array}{l}0.055 \\
(0.137)\end{array}$ & $\begin{array}{l}-0.025 \\
(0.062)\end{array}$ & $\begin{array}{l}-0.020 \\
(0.050)\end{array}$ & $\begin{array}{l}-0.010 \\
(0.026)\end{array}$ \\
\hline$\%$ of married respondent & $\begin{array}{l}-0.063 \\
(0.158)\end{array}$ & $\begin{array}{l}0.028 \\
(0.071)\end{array}$ & $\begin{array}{l}0.023 \\
(0.059)\end{array}$ & $\begin{array}{l}0.012 \\
(0.030)\end{array}$ \\
\hline Age of respondent & $\begin{array}{l}0.004 \\
(0.005)\end{array}$ & $\begin{array}{l}-0.002 \\
(0.002)\end{array}$ & $\begin{array}{l}-0.002 \\
(0.002)\end{array}$ & $\begin{array}{l}-0.001 \\
(0.001)\end{array}$ \\
\hline Avg years of education of respondent & $\begin{array}{l}0.046^{* *} \\
(0.026)\end{array}$ & $\begin{array}{l}-0.020^{*} \\
(0.011)\end{array}$ & $\begin{array}{l}-0.017 * \\
(0.011)\end{array}$ & $\begin{array}{l}-0.008 \\
(0.006)\end{array}$ \\
\hline Total land size (Acre) & $\begin{array}{l}0.008 \\
(0.016)\end{array}$ & $\begin{array}{l}-0.003 \\
(0.007)\end{array}$ & $\begin{array}{l}-0.003 \\
(0.006)\end{array}$ & $\begin{array}{l}-0.001 \\
(0.003)\end{array}$ \\
\hline Training received on PHL & $\begin{array}{l}-0.240 \\
(0.151)\end{array}$ & $\begin{array}{l}0.107 \\
(0.069)\end{array}$ & $\begin{array}{l}0.088 \\
(0.055)\end{array}$ & $\begin{array}{l}0.044 \\
(0.031)\end{array}$ \\
\hline Fresh OFSP harvest (in $100 \mathrm{~kg}$ bag) & $\begin{array}{l}-0.006 \\
(0.004)\end{array}$ & $\begin{array}{l}0.003 \\
(0.002)\end{array}$ & $\begin{array}{l}0.002 \\
(0.002)\end{array}$ & $\begin{array}{l}0.001 \\
(0.001)\end{array}$ \\
\hline District & $\begin{array}{l}0.278 * \\
(0.151)\end{array}$ & $\begin{array}{l}-0.124 \\
(0.112)\end{array}$ & $\begin{array}{l}-0.102 \\
(0.089)\end{array}$ & $\begin{array}{l}-0.051 \\
(0.049)\end{array}$ \\
\hline Local Market & $\begin{array}{l}0.184 \\
(0.248)\end{array}$ & $\begin{array}{l}-0.083 \\
(0.106)\end{array}$ & $\begin{array}{l}-0.067 \\
(0.094)\end{array}$ & $\begin{array}{l}-0.034 \\
(0.056)\end{array}$ \\
\hline Urban Market & $\begin{array}{l}-0.233 \\
(0.239)\end{array}$ & $\begin{array}{l}0.039 \\
(0.062)\end{array}$ & $\begin{array}{l}0.097 \\
(0.104)\end{array}$ & $\begin{array}{l}0.097 \\
(0.123)\end{array}$ \\
\hline
\end{tabular}

Standard errors in parentheses $* * * \mathrm{p}<0.01, * * \mathrm{p}<0.05, * \mathrm{p}<0.1$

Although we provide the estimation of marginal effects only for one stage we estimated marginal effects for all 6 stages of OFSP value chain. The marginal effect estimations for all stages are consistent with their main parameter estimates. To save space we omit 5 other similar tables of marginal effect estimation, nonetheless, they are available upon request

stage, and which, if improved, could generate more effective value chains for smallholder producers. With respect to maize value chain, our results suggest a number of sensitive stages: (1) at de-husking stage, use of sticks, knives etc. versus bare hands, (2) at transport to home stage, use of trucks versus bicycle, (3) at drying stage, use of plastic sheets versus tarpaulin, (4) at shelling stage, beating cobs in sack with sticks versus shelling with bare hands, (5) at storage stage, storing in brick and mortar store rooms versus storing in living room in the house, (6) at selling stage, selling in local market versus selling at farmgate, and (7) at milling stage, use of manual milling versus commercial hammer mills. With respect to fresh WFSP value chain, our findings indicate two sensitive stages: (1) at transport to home stage, roots carried in containers (or baskets) versus roots placed in sacks and carried by hands, and (2) at storage stage, storing in kitchen hut or in brick and mortar store rooms versus storing in living room in the house. With respect to fresh OFSP value chain, our results suggest one sensitive stage: (1) at transport to home stage, using motorcycle versus roots placed in sacks and carried by hands. At each of these stages, the use of alternate methods could generate statistically significant gains.

These findings indicate that farmers could improve the efficiency of value chains through changes in postharvest practices. These practices could include the use of covered or raised drying areas, of accurate techniques for assessing grain moisture content, of drying and shelling machines, and of improved storage protection methods. Alongside the improvement of farmers' postharvest methods, awareness and training on postharvest management can help reduce quantitative postharvest losses along each node of the commodity value chains. Finally, it is important to recognise that this study, like many others is based on respondents' selfreported perceptions of the postharvest losses occurring at each postharvest value chain stage. The loss figures presented are thus 'perceptions' and thus subjective and not to be confused with 'measured assessments of postharvest loss'. We carefully designed the questionnaire and elicited farmers perception of postharvest losses at each stage of commodity value chains through a visual exercise implemented by trained enumerators proficient with local languages.

Acknowledgements This research was supported by Nutritional Postharvest Loss Estimation Methodology (NUTRI-P-LOSS) project led by Natural Resources Institute, University of Greenwich, funded by UK's Department for International Development (DFID) under the research initiative known as IMMANA or Innovative Metrics and Methods for Agriculture and Nutrition Actions. We appreciate the logistical support provided by International Potato Centre (CIP) in Uganda and the National Agricultural Research Organization (NARO), Uganda during this study. The opinions expressed in this paper do not necessarily reflect the views of our donor or partners.

\section{Compliance with ethical standards}

Conflict of interest The authors declared that they have no conflict of interest. 
Open Access This article is distributed under the terms of the Creative Commons Attribution 4.0 International License (http:// creativecommons.org/licenses/by/4.0/), which permits unrestricted use, distribution, and reproduction in any medium, provided you give appropriate credit to the original author(s) and the source, provide a link to the Creative Commons license, and indicate if changes were made.

\section{References}

Abass, A. B., Ndunguru, G., Mamiro, P., Alenkhe, B., Mlingi, N., \& Bekunda, M. (2014). Post-harvest food losses in a maize-based farming system of semi-arid savannah area of Tanzania. Journal of Stored Products Research, 57, 49-57.

Affognon, H., Mutungi, C., Sanginga, P., \& Borgemeister, C. (2015). Unpacking postharvest losses in sub-Saharan Africa: A meta-analysis. World Development, 66, 49-68.

AGRA. (2014). Establishing the status of postharvest losses and storage for major staple crops in eleven African countries (phase II). AGRA: Nairobi, Kenya.

Aina, A. J., Falade, K. O., Akingbala, J. O., \& Titus, P. (2009). Physicochemical properties of twenty-one Caribbean sweet potato cultivars. International Journal of Food Science and Technology, 44, 16961704.

APHLIS, 2018. The African Postharvest Losses Information System. www.aphlis.net

Baoua, I. B., Amadou, L., Ousmane, B., Baributsa, D., \& Murdock, L. L. (2014). PICS bags for post-harvest storage of maize grain in West Africa. Journal of Stored Products Research, 58, 20-28.

Bashaasha, B., Mwanga, R.O.M., Ocitti, P., Obwoya, C., and Ewell, P.T. 1995. Sweetpotato in the farming and food systems of Uganda: A farm survey report. International potato center (CIP) and National Agricultural Research Organization (NARO).

Bechoff, A., Westby, A., Owori, C., Menya, G., Dhuique-Mayer, C., Dufour, D., \& Tomlins, K. (2010). Effect of drying and storage on the degradation of carotenoids in orange-fleshed sweet potato varieties. Journal of the Science of Food and Agriculture, 90, 622-629.

Bokusheva, R., Finger, R., Fischler, M., Berlin, R., Marin, Y., Perez, F., \& Paiz, F. (2012). Factors determining the adoption and impact of a postharvest storage technology. Food Security, 4(2), 279-293.

Davidson, R., \& MacKinnon, J. G. (2003). Econometric theory and methods. New York: Oxford University Press.

FAO, IFAD, WFP (forthcoming, 2019). Food loss analysis: Causes and solutions: Case studies in the small-scale agriculture and fisheries sub-sectors. The Republic of Uganda: Beans, maize, sunflower and replication studies. Rome, FAO.

FAO, IFAD, UNICEF, WFP, \& WHO. (2018). The state of food security and nutrition in the world 2018: Building climate resilience for food security and nutrition. FAO: Rome.

Food and Agriculture Organization. (2011). Global food losses and food waste: Extent, causes, and prevention. Italy: Rome.

Food and Agriculture Organization of the United Nations. (2009). How to feed the world in 2050; food and agriculture Organization of the United. Rome, Italy: Nations.

Gibbon, P., \& Ponte, S. (2005). Trading down: Africa, value chains, and the global economy. Philadelphia: Temple University Press Retrieved from http://www.jstor.org/stable/j.ctt14bs8v1.

Gitonga, Z. M., De Groote, H., Kassie, M., \& Tefera, T. (2013). Impact of metal silos on households' maize storage, storage losses and food security: An application of a propensity score matching. Food Policy, 43, 44-55.

Global Strategy to improve Agricultural and Rural Statistics (GSARS). (2017). Field test report on the estimation of crop yields and post- harvest losses in Ghana. In Global strategy technical report GO-292017 (53 pp). Rome: FAO.

Harris, K. L., \& Lindblad, C. J. (1978). Postharvest grain loss assessment methods: A manual of methods for the evaluation of postharvest losses. In 193 pp. American Association Cereal: Chemists.

Hengsdijk, H., \& de Boer, W. J. (2017). Post-harvest management and post-harvest losses of cereals in Ethiopia. Food Security, 9, 945 958.

Hodges, R. J. (2013). How to assess postharvest cereal losses and their impact on grain supply: Rapid weight loss estimation and the calculation of cumulative cereal losses with the support of APHLIS (121 pp). UK: Natural Resources Institute.

Hodges, R.J., Benard, M., Rembold, F., 2014. APHLIS - Postharvest cereal losses in sub-Saharan Africa, their estimation, assessment and reduction. European Commission JRC Technical Reports. 177 pp.

Hodges, R. J., Buzby, J. C., \& Bennett, B. (2011). Postharvest losses and waste in developed and less developed countries: Opportunities to improve resource use. The Journal of Agricultural Science, 149, 37 45.

Kaminski, J., \& Christiaensen, L. (2014). Post-harvest loss in subSaharan Africa-What do farmers say? Global Food Security., 3(3), 149-158.

Kikulwe, E. M., Okurut, S., Ajambo, S., Nowakunda, K., Stoian, D., \& Naziri, D. (2018). Postharvest losses and their determinants: A challenge to creating a sustainable cooking Banana value chain in Uganda. Sustainability, 10, 2381. https://doi.org/10.3390/ su10072381.

McKelvey, R. D., \& Zavoina, W. A. (1975). Statistical model for the analysis of ordinal level dependent variables. J Math Soc., 4(1), $103-120$

Mebratie, M. A., Haji, J., Woldetsadik, K., \& Ayalew, A. (2015). Determinants of postharvest banana loss in the marketing chain of Central Ethiopia. Food Science and Quality Management, 37, 5263.

Mlambo, S., Mvumi, B. M., Stathers, T. E., Mubayiwa, M., \& Nyabako, T. (2017). Field efficacy of hermetic and other maize grain storage options under smallholder farmer management. Crop Protection, 98 , 198-210.

Mvumi, B. M., Giga, D. P., \& Chiuswa, D. V. (1995). The maize (Zea mays L.) post-production practices of smallholder farmers in Zimbabwe: Findings from surveys. Journal of Applied Science for Southern Africa, 4(2), 115-130.

Mwanga, R. O. M., \& Ssemakula, G. (2011). Orange-fleshed sweetpotatoes for food, health and wealth in Uganda. International Journal of Agricultural Sustainability, 9(1), 42-49.

Ndegwa, M. K., De Groote, H., Gitonga, Z. M., \& Bruce, A. Y. (2016). Effectiveness and economics of hermetic bags for maize storage: Results of a randomized controlled trial in Kenya. Crop Protection, 90, 17-26.

Ng'ang'a, J., Mutungi, C., Imathiu, S. M., \& Affognon, H. (2016). Low permeability triple-layer plastic bags prevent losses of maize caused by insects in rural on-farm stores. Food Security, 8, 1-13.

Omotilewa, O. J., Ricker-Gilbert, J., Ainembabazi, J. H., \& Shively, G. E. (2018). Does improved storage technology promote modern input use and food security? Evidence from a randomized trial in Uganda. Journal of Development Economics, 135, 176-198.

Osundahunsi, O. F., Fagbemi, T. N., Kesselman, E., \& Shimoni, E. (2003). Comparison of the physicochemical properties and pasting characteristics of flour and starch from red and white sweet potato cultivars. Journal of Agriculture and Food Chemistry, 51, 2232-2236.

Parmar, A., Hensel, O., \& Sturm, B. (2017). Post-harvest handling practices and associated food losses and limitations in the sweet potato value chain of southern Ethiopia. NJAS -Wageningen Journal of Life Sciences, 80, 65-74.

Prusky, D. (2011). Reduction of the incidence of postharvest quality losses, and future prospects. Food Security, 3(4), 463-474. 
Sheahan, M., \& Barrett, C. B. (2017). Review: Food loss and waste in sub-Saharan Africa. Food Policy, 70, 1-12.

Stathers, T. E. (2019). Chapter 31: Challenges and initiatives in reducing postharvest food losses and food waste: Sub-Saharan Africa. In M. Yahia (Ed.), Preventing food losses and waste to achieve food security and sustainability. Cambridge: Burleigh Dodds Science Publishing.

Stathers, T., Lamboll, R., \& Mvumi, B. M. (2013). Postharvest agriculture in changing climates: Its importance to African smallholder farmers. Food Security, 5, 361-392.

Stathers, T., Ognakossan, K.E., Priebe, J., Mvumi, B.M., Tran, B.M.D., 2018. Counting losses to cut losses: quantifying legume postharvest losses to help achieve food and nutrition security. In: Adler, C.S., Opit, G., Furstenau, B., Muller-Blenkle, C., Kern, P., Arthur, F.H., Athanassiou, C.G., Bartosik, R., Campbell, J., Carvalho, M.O., Chayaprasert, W., Fields, P., Li, Z., Maier, D., Nayak, M., Nukenina, E., Obeng-Ofori, D., Philips, T., Riudavets, J., Throne, J., Scholler, M., Stejskal, V., Talwana, H., Timlick, B., Tremattera, P., (Eds.). Proceedings of the 12th International Working Conference on Stored Product Protection, Berlin, Germany, 7-11 October 2018. pp 8-18.

Tefera, T., Kanampiu, F., De Groote, H., Hellin, J., Mugo, S., Kimenju, S., Beyene, Y., Boddupalli, P. M., Shiferaw, B., \& Banziger, M. (2011). The metal silo: An effective grain storage technology for reducing post-harvest insect and pathogen losses in maize while improving smallholder farmers' food security in developing countries. Crop Protection, 30, 240-245.

Tesfaye, W., \& Tirivayi, N. (2018). The effect of improved storage innovations on food security and welfare in Ethiopia. Food Policy, 75, 52-67.

Uganda Bureau of Statistics. (2017). The national population and housing census 2014 - Area specific profile series. Uganda: Kampla.

Wooldridge, J. M. (2010). Econometric analysis of cross section and panel data. Cambridge, MA: MIT Press.

World Bank, NRI, FAO., 2011. Missing food: The case of post-harvest grain losses in sub-Saharan Africa. In: Economic sector work report no. 60371-AFR. World Bank, Washington, DC.

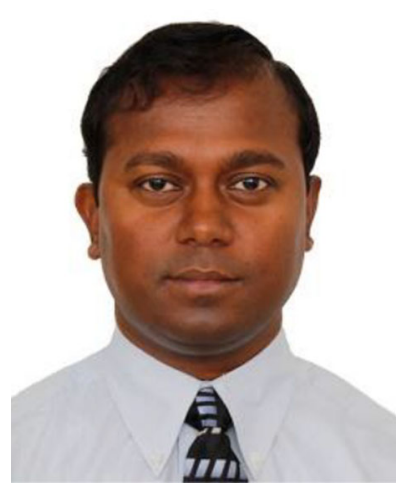

Dr Apurba Shee is a Business Development Economist and Senior Lecturer at the Natural Resources Institute (NRI) in University of Greenwich. Prior to joining NRI, Apurba worked at the International Food Policy Research Institute (IFPRI) and the International Livestock Research Institute (ILRI) and conducted applied economic research in Kenya, Tanzania, Malawi, Zambia, Ethiopia, Ghana, Mali, and India. Apurba holds a M.S. in Applied Economics and Management from Cornell University and a Ph.D. in Applied Economics from Penn State University. Apurba's main research interest lies in applied microeconomics, with a special interest in agricultural finance, development and applied econometrics. His research aims at evidence based policy interventions for agricultural development to increase resilience and reduce vulnerability for rural population. His research includes impact assessment of agricultural technologies using household-level survey data, design and development of microinsurance and microcredit instruments, productivity and efficiency analysis, and agri-food value chain analysis.

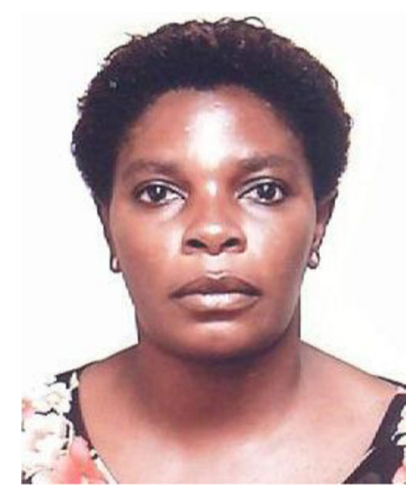

Sarah Mayanja is a Research Associate with the International Potato Center (CIP); based in Uganda. She has experience in agricultural trade development, agricultural marketing, gender responsive value chain development and post-harvest research She is a PhD Fellow at the Uganda Martyrs University and her research is focusing on sweetpotato root and seed market chains.

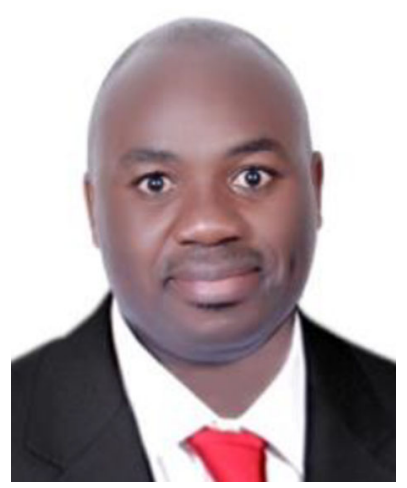

Mr Eria Bwana - Simba is an Information Management Specialist at the National Agricultural Research Organisation (NARO) in Uganda. Eria holds a Bachelor of Library and Information Science, and an MSc. in Information Systems from Makerere University. Eria's thrust has been in the designing and deployment of information systems to support NARO's stakeholders in making informed (evidence-based) strategic decisions. Eria is involved in African Postharvest Losses Information System (APHLIS), an international effort to collect, analyze and disseminate data on postharvest losses of cereal grains in sub-Saharan Africa; he is the focal person for Uganda. His work also involves using a voucher system to enhance access to online information to researchers, extension agents and farmers in rural parts of Uganda.

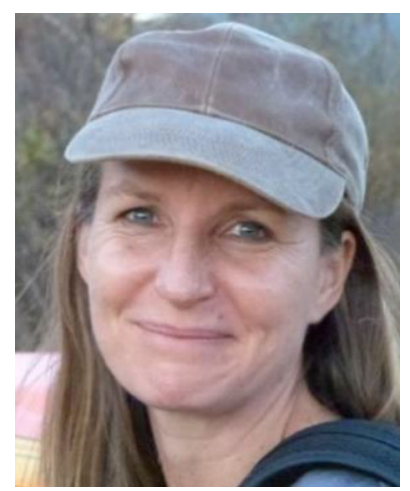

Tanya Stathers has worked as an agriculture for development researcher across sub-Saharan Africa for $>25$ years, with a particular focus on: postharvest systems and the reduction and understanding of postharvest losses (including their nutritional and financial value) in staple grains and roots and tuber crops; multi-stakeholder learning processes; agricultural adaptation to climatic and other changes; creative training materials and approaches; ruralurban interdependencies; gender and diversity aspects of agri-food systems; and poverty impacts of market standards. Her earlier work focused on: participatory development of pre and postharvest integrated pest management options for a range of smallholder produced cash and food crops; including diatomaceous earth grain protectants, entomopathogenic fungi, pheromones, natural enemies, resistant varieties and the farmer field school approach. She also supervises postgraduate research students and has developed and teaches on several training courses. She is a principal scientist at the Natural Resources Institute (NRI) of University of Greenwich. 


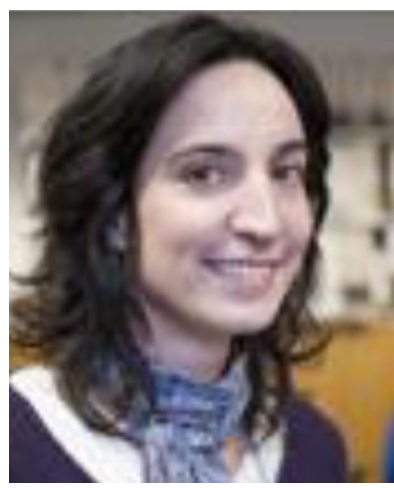

Dr Aurélie Bechoff is a Food technologist at the Natural Resources Institute (NRI) in University of Greenwich. Dr. Bechoff has field experience in sub-Saharan Africa (more than 15 countries), Asia and Latin America. Aurélie holds a Ph.D. in Food Technology applied to Low-Middle Income Countries from NRI. Aurélie's main research interest lies in the interface between food technology, consumer research, and nutrition, with a specific interest in nutrient loss within the food system. Her main expertise is on the effect of drying and storage on carotenoid retention in roots and tubers (sweet potato, cassava). Lately she has been leading a DFID-funded project called NUTRI-P-LOSS on the development of a methodology for estimating nutritional postharvest losses, from harvest to market, for three key crops for food security - sweet potato, maize, cowpea - in Zimbabwe and Uganda.

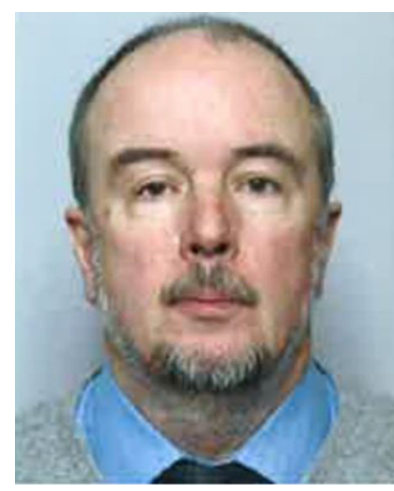

Prof Ben Bennett is a Trade and Marketing Economist and Deputy Director of the Natural Resources Institute (NRI), University of Greenwich where he also leads the Centre for Food Loss and Waste Reduction (FLoW). Prof Bennett has provided research and advice in over 40 LMIC's in a wide range products and production systems. This has included long-term assignments in Nigeria, the Philippines and Namibia. His interests include work on value chains and postharvest economics, postharvest losses, developing markets for novel products and orphan crops and many aspects of natural product trade. Recent research includes aspects of food safety, market information systems, food fortification, livestock value chains and the economics of food processing and preservation. 